\title{
REMAINING COMPETITIVE IN THE GLOBAL ECONOMY THROUGH TEMPORARY MIGRANT LABOUR? ONE "SHORT-TERM" STEP FORWARD AND TWO "LONG-TERM” STEPS BACKWARD IN CANADIAN IMMIGRATION
}

By

Patrick Michael Sullivan, BA, Simon Fraser University, 2009

\author{
A Major Research Paper \\ Presented to Ryerson University \\ In partial fulfillment of the requirements for the degree of \\ Master of Arts \\ in the Program of \\ Immigration and Settlement Studies
}

Toronto, Ontario, Canada, 2012

(C) Patrick Sullivan 2012 
I hereby declare that I am the sole author of this Major Research Paper. This is a true copy of the MRP, including any required final revisions, as accepted by my examiners.

I authorize Ryerson University to lend this MRP to other institutions or individuals for the purpose of scholarly research.

I further authorize Ryerson University to reproduce this MRP by photocopying or by other means, in total or in part, at the request of other institutions or individuals for the purpose of scholarly research.

I understand that my MRP may be made electronically available to the public. 


\title{
REMAINING COMPETITIVE IN THE GLOBAL ECONOMY THROUGH THE PILOT PROJECT FOR OCCUPATIONS REQUIRING LOWER LEVELS OF FORMAL TRAINING: ONE "SHORT-TERM" STEP FORWARD AND TWO "LONG- TERM” STEPS BACKWARD
}

\author{
Patrick Michael Sullivan \\ Master of Arts, 2012 \\ Immigration and Settlement Studies \\ Ryerson University
}

\begin{abstract}
In the last 10 years, the creation and expansion of the Low Skill Pilot Project (LSPP) has substantially increased the scope of the Temporary Foreign Worker Program, ultimately eclipsing permanent immigration into Canada. The consequences, while positive for employers in the short-term, are perverse for Canada's principles of social justice and equity in the long-term. It is also not clear whether the Project serves Canada's immigration goals and national interests in the long term. This paper examines the LSPP's creation and development, and analyzes short and long-term implications for Canadian society and the "Canada brand" of immigration, which refers to Canada's image as a "destination of choice" for would-be immigrants the world over. This paper draws attention to the dichotomy of labour rights, wages and benefits of skilled and unskilled temporary foreign workers. A juxtaposition of two foreign worker categories within a dual labour segmentation framework illustrates this phenomenon.
\end{abstract}

\section{Key words:}

Pilot Project for Occupations Requiring Lower Levels of Formal Training; temporary foreign worker; exclusion; citizenship; labour shortage; Temporary Foreign Worker Program. 


\section{List of Acronyms:}

Temporary Foreign Worker Program (TFWP)

Low Skill Pilot Project (LSPP)

Occupations under pressures (OUP)

Regional Occupations Under Pressure" (ROUP)

Expedited Labour Market Opinion" (E-LMO)

Accelerated Labour Market Opinion” (A-LMO) 


\section{Table of Contents}

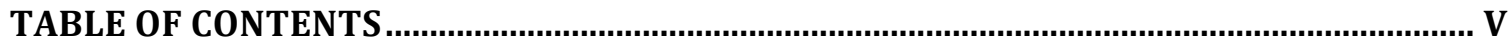

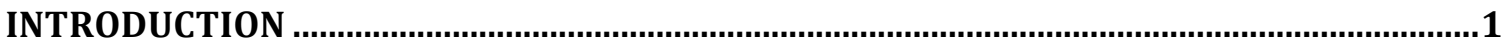

PURPOSE AND RELEVANCE ...................................................................................................4

METHODS AND SEARCH STRATEGY …………………………………………………….....6

I. THEORETICAL DISCUSSION: LABOUR SEGMENTATION THEORY VS. EQUILIBRIUM

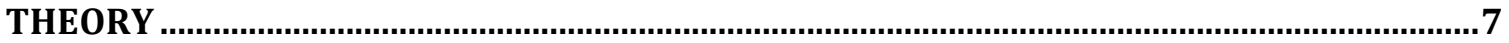

II. CONTEXT: THE BIRTH AND GROWTH OF CANADA'S TEMPORARY MIGRANT

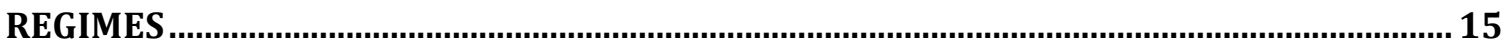

III. EXCLUSION AND INCLUSION OF LOW-HIGH SKILLED MIGRANTS ...............................21

IV. CITIZENSHIP AND THE SEGMENTATION OF THE LABOUR MARKET ……………….... 28

V. HOW MIGRANT LABOUR IS SEEN AS A STRUCTURAL NECESSITY .................................36

VI. IMPLICATIONS OF A CONTINUED EXPANSION OF THE TFWP'S LSPP ......................... 43

I. INCREASED OUTFLOWS OF MONEY FROM CANADA …………………………………………….... 47

- RECOMMENDATION....................................................................................................................49

II. DECLINE IN DOMESTIC TRAINING AND APPRENTICESHIP PROGRAMS .....................................50

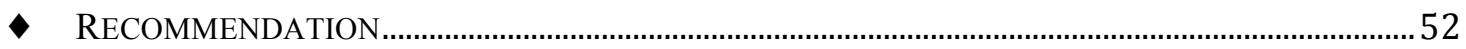

III. THE RISE OF CANADIAN RESENTMENT TOWARDS IMMIGRATION ...........................................5



IV. SOCIO-ECONOMIC POLARIZATION ……………………………………………………………. 58

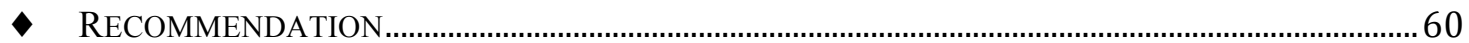

V. THE RISE OF AN UNDOCUMENTED UNDERCLASS.....................................................................62

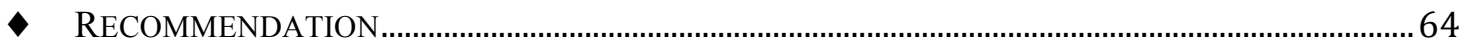

VI. THE "CANADA BRAND" WILl Be Damaged OR DEVALUED .......................................................66

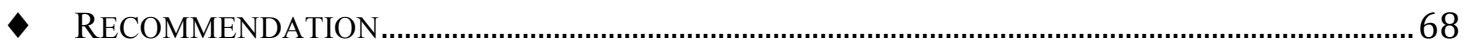

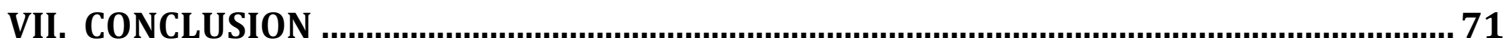

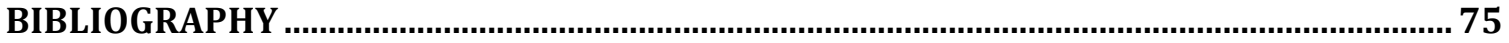




\section{Introduction}

For post-industrial countries the advent of higher levels of per capita education, increased productivity, rising incomes, low birthrates/population aging, and the globalization of manufacturing have combined to bring structural changes to how their labour markets are regulated. In this restructuring, globalization has increased intercountry wage disparities to unprecedented levels, stimulating more people to migrate through various immigration and temporary migrant regimes (Bagchi 2008, 202). As a result, Canada has started to follow a European trend migration trend, which places more emphasis on temporary labour migration than on permanent immigration. This paradigm shift to complex policies, which facilitates the entrance of skilled migrants whilst conditioning that of the unskilled, contrasts with previous eras of immigration. The Organization for Economic Cooperation and Development (OECD) reports that its member's use of temporary migrant regimes (in terms of the number of admittances) have increased by $4 \%$ and 5\% per year globally since the year 2000 (Chaloff \& Lemaitre 2009, 31). In fact, Australia, Canada, the United States, and New Zealand, traditionally countries of permanent settlement, accepted 1.24 million temporary migrant workers in 2005-2006 alone (Goldin et al. 2011, 132).

In Canada, this policy shift from permanent to temporary migrant regimes has reached a tipping point. Since 2009, the Temporary Foreign Worker Program (TFWP) has received more temporary foreign workers than the Federal Skilled Worker Program (FSWP) has received permanent residents, 281,349 and 252,172 entries respectively (CIC 2010a). The latest statistics from Citizenship and Immigration Canada, which are from 
the year 2010 , confirm this permanent to temporary shift: the 282,771 temporary foreign workers admitted in 2010 have again eclipsed the Federal Skilled Worker Program's 280,681 arrivals (CIC 2010a). Traditionally, the federal system has been based on bringing in immigrants to fully participate and integrate into the country - with the overall intention to eventually produce new Canadian citizens. Although the TFWP in its earlier form (Non-Immigrant Employment Authorization Program) has long had a twotiered system - for example, seasonal agricultural workers have never been permitted to permanently settle in Canada (Austin and Bauder 2010, 7) - the recent implementation of the TFWP's the Pilot Project for Occupations Requiring Lower Levels of Formal Training (here after referred to as the Low skilled Pilot Project (LSPP)) ${ }^{1}$ has dramatically increased the size and breadth of the second-tier half of the program.

The LSPP, which began in 2002, has increased from the initial inflow of 1,304 migrants per year, to 37,193 in 2009 (CIC 2010a). These figures are significant as they highlight Citizenship and Immigration Canada's (CIC) policy direction: increasing the numbers of unskilled migrants brought into Canada (without any realistic pathways to citizenship) to occupy "permanently temporary" labour market shortages. Immigration policy has espoused a two-tiered immigration system based on workers' skill levels to determine access to services and rights. On the one hand, there is the first-tier, composed of "skilled" workers who are granted the traditional full set of rights, settlement services

${ }^{1}$ The LSPP permits migrants with "lower" levels of human capital or formal training to enter Canada on a temporary basis. This pilot project allows Canadian employers to recruit migrants for National Occupation Classification positions that usually do not require more than a high school education (HRSDC 2012b).

${ }^{2}$ In this primary segment, which is generally composed of local skilled resident and 
and pathways to citizenship. On the other hand, there is the second-tier (mostly seasonal agricultural workers and LSPP migrants), composed of "unskilled" workers, who are restricted from accessing equal sets of rights, settlement services, and pathways to citizenship.

Conversely, this shift has left unskilled temporary foreign workers at the margins of membership rights and socio-economic development in their arrival countries (Dobrowolsky 2011). Temporary foreign workers' access to citizenship has restricted their access to membership rights; in the sense that they are restricted from participating in the democratic process of the country they are brought into work and live. In the same vein, temporary foreign workers' exclusion from access to social services (social welfare programs, social services, and subsidized education) inhibits their socio-economic development.

This context raises two questions. First, why are post-industrial countries increasingly adopting temporary migrant regimes that in many cases are permanently temporary? Second, how does restructuring of labour markets (partly through immigration policies and increased use of migrant labour) affect notions and rights of citizenship? And how do changes in citizenship regimes (constructed and conditioned by the state and influenced by organized capital), affect the restructuring of labour markets in Canada? This paper will demonstrate how cost saving measures such as decentralizing immigration programs through the devolution of responsibility to the private sector, coupled with the state's power to construct and condition the parameters of citizenship have been seen by the Canadian government as ways to keep Canada globally competitive. This is accomplished by disciplining its labour market through the use of the 
TFWP, thereby reducing wages, labour rights and benefits. Identifying the driving forces leading to this trend is imperative if we are to understand Canada's future development trajectory and the decline in the value system upon which it has hitherto developed.

\section{Purpose and Relevance}

This paper aims to identify and investigate the principle drivers fomenting the TFWP's expansion through the LSPP; to demonstrate the nexus between global wage disparities and inequality, citizenship, and labour markets in shaping immigration policy in Canada; to illustrate the short and long-term implications of reducing permanent immigration flows in favour of temporary migrant regimes; and to provide a critical analysis from which future research can draw upon. Current discourses about the TFWP have been confined to academic and policy circles, with the odd tragic event surfacing in the media (Gray 2011; Chidley 2012; Pacholik 2012). Given the harmful impact the TFWP holds and will continue to bear on society, it is timely that more material be made available for discussion. For this to occur, the issues need to transcend academic and policy circles and capture the public's interest. Canadians can influence how democracy, citizenship, labour markets, wages, benefits, and work conditions will affect not only Canadian residents and their future generations, but also future/new Canadians (or not). Canada has reached a crossroad. Canada can be more egalitarian and inclusionary, or choose a more exclusionary road toward citizenship, labour markets, wages and benefits.

Temporary migrant regimes in post-industrial countries have expanded 
dramatically, leaving large swaths of migrants at the margins of socio-economic development and membership rights. This problem is relevant because it illustrates the change in ideology and practice regarding immigration programs in post-industrial countries. The problem of diminished access to citizenship in this continued expansion of temporary migrant regimes has the potential to fundamentally alter post-industrial countries' socio-economic fabric, whereby the "haves" live in stark contrast to the "havenots." Academics, policy analysts, community and not-for-profit groups' current preoccupation about the short and long-term consequences the TFWP will have on Canadian civil society provide the impetus for this study. Given Canada's fundamental reliance on immigration to fuel economic and demographic growth, it is of the outmost importance to investigate and evaluate the effects these shifts in immigration policy may have on (im)migrants to Canada.

To understand the expansion of temporary migrant regimes, this paper will first discuss labour segmentation theory and equilibrium theory to provide an analytical lens from which to comprehend and approach the expansion of temporary migrant regimes. Second, it will analyze the synergy between neoliberal restructuring and citizenship in contemporary post-industrial countries (using Canada as an example). Third, it will discuss the structural role migrant labour plays in Canada. Fourth, it will outline the longterm implications of continuing to expand the TFWP's LSPP, followed by policy recommendations. Lastly, it will conclude with some closing remarks.

The premise of this paper is that LSPP migrants, by virtue of their "temporary status" and being unaware, misinformed or unable to use national and domestic regulations, are vulnerable to abuse. This paper focuses strictly on LSPP migrants and the 
precariousness of their status. Although it is evident that live-in caregivers and seasonal agricultural workers are also vulnerable, they will not be studied. These groups are outside the scope of this paper. In addition, it is recognized that racialization and gender are also prevalent themes of the LSPP migrant discourse. However, this study takes a broad approach to analyzing the systemic forces (neoliberalism and its relation to the state, labour and citizenship) driving Canada's two-tiered immigration regime, and thus will not pursue these cross-cutting themes.

\section{Methods and Search Strategy}

This paper draws information and insight mainly from published scholarly and public sources such as academic journals, reports, books, and other publications. Although temporary migrant regimes are global in scope, my search focused mainly on the Canadian situation. While there has been an abundance of literature written about the TFWP's SAWP between the 1980s and the year 2000, there has been far less available about the LSPP, mostly due to the project's infancy (it was enacted and implemented in 2002). Concomitantly, my search strategy excluded most literature published before 2002, which would pertain to the NIEAP or SAWP, with the exception of theoretical literature about labour segmentation theory. This remains highly relevant and applicable to the new LSPP.

Literature published after 2002 to the present was included in the search strategy. In addition, and perhaps due to the topic's wide-ranging effect on various societal actors, the search also included policy papers and labour union reports about the LSPP. Searches 
were performed at Ryerson University's library and online on the following databases: Google scholar, Proquest Research Library Complete, Project Muse, SpringerLink, and Jstor, Sociological Abstracts, and Social Science Abstract. Key words and terms used in the search to find relevant material were: migrant; unskilled; temporary; foreign labour; Temporary Foreign Worker Program; Pilot Project for Occupations Requiring LowerLevels of Formal Training (LSPP), and international migration. Reports were retrieved from the websites of research institutes and unions such as the CERIS - The Ontario Metropolis Centre and The British Columbia Metropolis Centre, FOCAL: Canadian Foundations for the Americas, The National Union Of Public And General Employees, and The Canadian Labour Congress. Throughout the paper, although mostly in section six, I pull quotes from current (2010-12) Canadian newsprint and online media sources and insert them to add richness and substance to both the implications and recommendations put forth.

\section{Theoretical Discussion: Labour Segmentation Theory vs. Equilibrium Theory}

In the study of labour migration and its most current manifestation - temporary migrant regimes - two theories fuel the debate: labour segmentation theory and equilibrium theory. These two theories are based on different sets of concerns and perspectives. The former is concerned with how the labour market is divided and structured into a hierarchy of segments through (im)migration. The latter is concerned with the behavior of supply and demand principles within national labour markets, which 
when interlocked with immigration and global wealth disparities provide strong arguments for the creation and implementation of temporary migrant regimes in postindustrial countries. Both theories involve tightly managed processes of labour controls of (im)migrants in both the countries of origin and receiving countries (Yang 2010; Bauder 2006, 25). In both theories, the state is seen to play a pivotal role in the development, operationalization and management of temporary migrant regimes.

In labour segmentation theory the labour market is divided in three segments: the primary segment ${ }^{2}$ (which is capital intensive), the middle segment ${ }^{3}$ (which is both capital and labour intensive), and the secondary ${ }^{4}$ (which is labour intensive). The technical/skill division of individuals - which create a considerable skills/rights dichotomy - in the primary and secondary segments, mirrors the distinction of capital and labour within the organization of post-industrial economies. On the one hand, the primary capital-intensive segment in which capital is fixed and thus can be working or idled by fluctuations in demand, but cannot be laid-off easily, leaves the owners and the state to bear the costs of unemployment. On the other hand, labour is variable, and in the case of migrants, who are resigned to the secondary segment of the labour market, can and are laid-off and/or

${ }^{2}$ In this primary segment, which is generally composed of local skilled resident and (im)migrant workers, labour conditions and job security are quite high. Generally speaking, workers situated in the primary segment enjoy optimal wages, working conditions and benefits.

${ }^{3}$ In the middle segment, which is composed of local resident workers and (im)migrant workers, wages, working conditions and benefits are also good. However, with the advent of global competition, industries employing middle segment workers are increasingly attempting to bring down wages, benefits and working conditions.

${ }^{4}$ In the secondary segment, which is composed of unskilled migrant workers and increasingly unskilled local resident workers, working conditions, wages and benefits are precarious. That is, workers earn less, receive minimal social benefits (extended healthcare, dental coverage, life insurance etc.), and do not have job security. 
repatriated during periods of economic contraction (Piore 1979, 36). Ultimately, the primary segment is constructed to meet the basic output demand, while the labourintensive secondary segment picks up the extra slack and/or seasonal demand (Piore 1979, 37). In this segmentation process, the middle segment (which is mostly composed of composed of non-migrants) is hollowed out through the use of temporary foreign workers. That is, the restriction imposed on migrant workers'rights enables employers to reduce the middle segments wages, working conditions and benefits and thus pushes such workers into the secondary segment.

Piore (1979) argues that this dichotomy provides the primary segment, who are generally composed of non-migrants, with skilled, safe and well-paid jobs; while the secondary segment, which is disproportionately composed of migrants, provides unskilled precarious, labour intensive, and poorly paid jobs that are undesirable to nonmigrant citizen workers and, thus require migrants to fill such positions (36). Worth noting, in addition to the migrants situated in this secondary segment, other marginalized groups such as racialized workers and women also inhabit part of the secondary segment of the labour market. In periods of economic contraction, the secondary segment is usually laid off. However, because of the heavy investment in capital-intensive technology in the primary segment, there are fewer losses to the owners of such "idle" capital and, by extension, to the loss of jobs in this primary segment (Bauder 2006, 20). From this perspective, temporary migrant regimes - which provide expandable/flexible labour - stabilize and sustain the primary labour market of non-migrants by absorbing economic cyclical volatility.

Globalization and socio-economic maturity in post-industrial countries has 
brought on sharp changes to their tradable ${ }^{5}$ and non-tradable ${ }^{6}$ labour sectors (Harris 2006, 102). Most commonly, the tradable labour sectors are more susceptible to being shipped off to low wage countries, while the non-tradable industries, which are generally situated in low-skilled sectors ${ }^{7}$ (health aides, hospitality, cleaning industry etc.) cannot be outsourced to cheaper offshore locations as they entail physically being within postindustrial countries. From this economic perspective, structural shifts through the aforementioned processes destroy old industrial sectors and create new centres of innovation or "knowledge economies" in what Joseph Schumpter (1994) coined "creative destruction," ${ }^{8}$ but on a global scale. The implications in terms of migration are serious. While capital flows and trade have been liberalized, the movement of people internationally has not. This means highly managed (im)migration regimes are susceptible to being influenced and guided by the logic of capital. Problematically, the confluence of unchecked capital interests and rigid immigration regimes can have adverse effects on migrant population in post-industrial countries.

${ }^{5}$ Tradable sector refers to parts of the economy that produce "tradable good" - usually the manufacturing sectors of the economy - that can be exported to world markets. Due to the liberalization of capital flows and the proliferation of free trade deals the world over, jobs in this sector are vulnerable to being outsourced to lower wage off-shore locations.

${ }^{6}$ Non-tradable sector refers to parts of the economy that produce "non-tradable goods and services" that cannot be exported to world markets. Due to the fact that jobs in the non-tradable sectors of post-industrial countries require workers to physically be in the country to provide or complete the good or service, jobs in this sector cannot be outsourced to lower wage off-shore locations.

${ }^{7}$ While skill level does not always determine whether or not the sector is tradable or nontradable, the bulk of the jobs that will be created in post-industrial countries will be in low skilled non-tradable sectors.

${ }^{8}$ This is the process of "industrial mutation" that revolutionizes economic structures from within, destroying old less efficient or dynamic mechanisms to consolidate or create new "leaner and meaner" industry or company (Schumpter 1994, 82). 
In contrast to labour segmentation theory, equilibrium theory espouses the aforementioned economic perspective. A common view from economists who apply this logic to theories on immigration is that migration occurs due to disequilibrium between developing countries and post-industrial countries in the supply of and demand for labour and the resulting wage differences; that is, push factors in developing countries are the drivers of migration (Yang 2010, 4). Pritchett (2006), a prominent development economist at Harvard and advocate for the application of temporary migrant regimes to achieve such equilibrium ${ }^{9}$, cites the rebalancing process that has taken place in the US over the last few decades - which saw labour gravitate/migrate from old declining industrial regions in a process of "creative destruction" to new innovative/capital-rich regions - as a model for liberalizing migrant flows internationally (23). From this perspective, an equilibrium model provides an "efficient" system to reallocate (rebalance) labour to where capital has created new engines of growth for it. That is, post-industrial countries adapt to changes in the structure of the global economy, through an "equilibrium" model, by shifting capital to areas where it works in tandem with research and innovation to create economic growth and jobs (Pritchett 2006). Moreover, he argues that a fully "globalized" world, whereby migration is liberalized to the same extent trade and financial flows are today, would be the most robust development tool to bridging wage and inter country inequality gaps.

\footnotetext{
${ }^{9}$ Equilibrium in this context is the balance of labour supply with labour demand through the movement of people to meet labour market demand. In this instance, Pritchett (2006) believes increasing flows of migrants through temporary migrant regimes will help alleviate disequilibrium in post-industrial countries' non-tradable labour markets.
} 
Problematically, many advocates of equilibrium theory - Pritchett (2006), Ruhs and Martin (2008), Lenard and Straehle (2010) - believe temporary migrant regimes are the vehicle with which this development tool should be delivered. According to this theory, temporary - as opposed to permanent - migration is preferable because it allows for a redistribution of wealth from the rich post-industrial countries to the poor Global South. Ruhs and Martin (2008) maintain that although migrants rights are curtailed through temporary migrant regimes, the continuation/expansion of temporary migrant regimes is justified from an international development perspective: this view argues that it is a "win-win-win" as migrant workers win by earning higher wages while working in receiving countries, post-industrial countries win by quickly filling "temporary" labour shortages and leveraging industrial output, and sending countries win through the increased flows of remittances and "skill/technology transfers" of returning migrants to the origin country (249). Lenard and Straehle (2010) argue, although migrants brought in to post-industrial countries through temporary migrant regimes are exploited, the range of benefits resulting from the global redistribution of wealth - through remittances - is justified. That is, it is necessary to sacrifice migrant rights to help redistribute wealth to the developing world (287). Further, they argue intervention in temporary migrant regimes' exploitative tenets/restrictions, which attempt to ameliorate migrants' membership rights in post-industrial countries, would impart greater harm than the harm caused by migration restrictions (285).

Development economists, including Pritchett (2006), believe temporary migrant regimes in post-industrial countries, which limit and restrict migrant rights, allow governments to bring in more migrants. The logic here is that the resident population's 
perceived tolerance threshold is higher when inbound migrants are not granted equal membership rights. By excluding migrants from access to social services and rights, Pritchett (2006) argues, post-industrial countries are able to bring in larger quantities of migrants and thus redistribute more wealth to the developing world. According to Lenard and Straehle (2010), remittance flows to the country of origin decline as migrants shift their allegiances upon receiving membership rights in the receiving country (293). This they argue justifies restricting migrants' membership rights so as to ensure the constant flow of remittances, and ultimately the North-South redistribution of wealth: "we ought to accept the rights restrictions imposed on temporary labour migrants, in exchange for the redistributive benefits that these restrictions will enable" (293).

While this "migration equilibrium development" model appears to be a good idea in principle, it is problematic in practice. Castles (2007), maintains evidence from sending countries suggests that without long-term strategies to reduce inequality, improve infrastructure, welfare and governance, remittance led strategies are "simplistic and naive." Proponents of this development view fail to acknowledge the inherent risks both migrants and, by extension resident workers are exposed to. It is problematic to refer to this as a development project when individual rights are curtailed on both sides of the border. According to Castles (2006) the "transfer of labour power and skills to the rich countries through labour migration is the latest form of development aid by the South to the North" (5). Moreover, they do not acknowledge the role bonded labour plays in disciplining post-industrial countries' domestic labour forces. For example, in Canada's case, the state has applied highly restrictive conditions on migrants' labour market mobility, leaving them exposed to precarious conditions. In addition, this development 
argument lacks a discussion about the current labour conflicts involving temporary foreign workers and labour unions.

In contrast to equilibrium theory, labour segmentation theory provides a more nuanced perspective from which to analyze labour migration to industrial countries. It posits that international migration is caused not by push factors in sending countries (i.e. low wages and unemployment) but by the demand for (im)migrant labour that is inherent to the shrinking labour pool ${ }^{10}$ of post-industrial countries (pull factors) (Yang 2010, 6). Rather than workers being the key players, employers and the state play the prominent role in driving and conditioning migration patterns into their respective labour market segments - demand comes mostly from the secondary labour market.

Understanding how the state and employers utilize the machinery of government - through rules and regulations design with high levels of involvement from capital - to divide (im)migrants into primary and secondary segments provides a rich lens from which to identify the impact temporary migrant inflows have on labour markets in postindustrial countries. In the following section, I will analyze the synergy between neoliberal restructuring and citizenship in contemporary post-industrial countries (using Canada as an example).

${ }^{10}$ As industrialized countries mature and become post-industrial countries, the combination of low birthrates and population aging prevent such countries from replacing the working age population. 


\section{Context: the Birth and Growth of Canada's Temporary Migrant Regimes}

Since the 1960s Canadian immigration policy has been transformed to suite the country's economic and demographic needs. The elimination of racial discrimination ${ }^{11}$ (1962) and the implementation of the point system ${ }^{12}$ (1967) to the immigrant selection criteria profoundly changed the nature of Canadian immigration ${ }^{13}$. The 1976 Immigration Act increased immigrant rights by emphasizing due process protection, generous family reunification, transparent admission criteria; and it ultimately reduced the power of the state by limiting the discretionary power of the minister and immigration officers. The rights of non-citizens in this era were provided high levels of protection (Kelley \& Trebilcock, 2010). This was useful because it provided (im)migrants settling in Canada with a blanket of protection necessary to establish roots and ties to local, regional and national communities. Nation building supported by an immigration system that protected and treated immigrants equally, played an important role in Canada's accent to “first world country" status (Yalnizyan 2012).

${ }^{11}$ This was a result of Canada's increased involvement in world affairs (General Agreement Tariffs and Trade, United Nations Relief and Rehabilitation Administration, and restorations of countries devastated by the Second World War) through the United Nations and other international organizations. In addition, the drying up of immigrant flows from traditional European countries galvanized Canada to recalibrate its immigration policy to not discriminate against racially diverse populations (Kelley \& Trebilcock 2010).

${ }^{12}$ The point system was designed to insure Canada attracted the world's best and brightest immigrants to fuel its "knowledge economy" (Green 2003).

${ }^{13}$ The major change besides the elimination of racial discrimination and the creation of the point system was the protection of basic due process. Greater concern over the rights of immigrants, engendered through the Immigration Appeal Board Act of 1967, characterize this period of Canadian immigration (Kelley \& Trebilcock 2010). 
Despite the gains made in protecting immigrant rights in the 1970s-80s, the Immigration and Refugee Protection Act (IRPA) implemented in 2002 neutralized and, in many cases, reversed the gains accrued. In this new era, immigration became more restrictive, driven in part by security concerns and not the business cycle. In addition, executive discretion in the form of ministerial instructions trumped the previous era's protective immigration legislation. Problematically, these new policy tools circumvent parliamentary over sight, resulting in the erosion of immigrant rights, protections, and checks and balances on executive power (Kelley \& Trebilcock, 2010).

Throughout this period, the rise of the neoliberal era in the 1970s unleashed enormous quantities of nationally constrained capital from developed industrial countries to the emerging developing world (McBride 2005, 96). Within this process, capital gravitated from traditional developed economies to low wage offshore locations. Global competition for talent has increased as a result of the emergence of new industrial countries, and the attempt of post-industrial countries to compete with these new dynamic competitors for the developing world's brightest minds (Watt, Krywulak, \& Kitagawa 2008). Increasingly, structural reforms, the expansion of trade, and the rise of the "knowledge economy" have deepened and widened the marketization of Canadian immigration policy (Dobrowolsky 2011, 112). In response, post-industrial countries recalibrated their immigration programs to restrict unskilled migrants and enable skilled migrants to access their territories (Bagchi 2008, 203). The ongoing pressure applied by 
organized capital, engendered through neoliberal ideology and practices ${ }^{14}$, has significantly affected the desire of post-industrial countries - like Canada - to accept full status immigrants (Castles and Miller 2009, 188). According to Marsden (2011), the logic of capital has come to govern the selection of permanent (im)migrants and the development of employer-driven temporary migrant regimes (60).

In Canada, the creation of the Non-Immigrant Employment Authorization Program (NIEAP) in 1973 coincided with the emergence of global neoliberalism, and marks the birth of Canada's first temporary migrant regime (Trumper \& Wong 2010). The NIEAP allowed workers in the services, manufacturing, agriculture, and domestic services to enter the country to alleviate labour shortages on a temporary basis - although permanently bound to their particular employer by restrictive work permits (Marsden 2011). In many cases, the labour shortages involved "dirty work" that did not appeal to Canadians, and thus required non-Canadians to be brought in to fill the shortages. According to Sharma (2006), "the NIEAP, ultimately, was structured to recruit workers through a category - non-immigrant - that rendered those brought through it as legally unfree" (98). These non-immigrants were legally permitted to enter the country; however, the labour market conditions imposed on them did not permit them to freely circulate in the Canadian labour market. If a non-immigrant was to leave his/her stipulated employer or change occupation, he/she would be subject to deportation (Sharma 2006, 105). In essence, foreign workers were to be brought in to do the dirty-dangerous-difficult work

\footnotetext{
${ }^{14}$ Essentially, the Canadian state retrenched from public programs so as to reduce its role in both the economy and social affairs. Affected realms of such retrenchment included fiscal policy, government employment, privatization, social, labour-market, and health policy (McBride 2005, 99).
} 
Canadians loathed. However, to insure foreign workers would not deviate from the undesirable work, they were legally categorized as non-immigrants - that is, they were not given the same rights skilled or full status immigrants received upon arrival (Sharma 2006, 98). Rights denied include but are not limited to the freedom to change employer, occupation, and province for which the migrant worker was assigned to in their work permit.

The enactment of the IRPA in 2002 highlights the federal government's continued neoliberal policy direction, which upgraded in immigration policy the value placed on human capital, and simultaneously downgraded the value of family and humanitarian classes (Dobrowolsky 2011, 117). In addition, the IRPA transformed the NIEAP into the TFWP, which not only maintained the NIEAP's temporary features (temporary work intervals, employer bound work permits, and limited pathways to citizenship), but also enhanced the government's ability to augment new TFWP policies and restrictions through ministerial instructions without parliamentary oversight (Marsden 2011; Nakache \& Kinoshita 2010). The increased emphasis of attracting economic immigrants with high levels of human capital, who are less costly to integrate, has to be the most salient feature built into the IRPA.

The explicit economic policy direction engendered through the IRPA divides migrants into two different streams: permanent and temporary. On the one hand, permanent residents are entitled to the same benefits and privileges citizens are granted, with the exception of the franchise (Galloway 2001, 187). On the other hand, unskilled migrants are allowed to access limited social services and entitlements while working in Canada, but are explicitly excluded from many benefits granted to immigrants (Marsden 
2011). This is consistent with the tenets of labour segmentation theory. Moreover, the permanent-temporary division commodifies temporary foreign workers into separate labour segments through rigid immigration laws. The state's use of a combination of policies specific to conditioning temporary foreign workers' status (or lack thereof), in this case, helps create and maintain a two-tiered/segmented labour market.

The retrenchment of the welfare state has influenced how post-industrial countries design and implement their immigration policies. This shift from full-status immigration (which included all immigrants in the settlement services) to temporary migration (which excludes unskilled migrants from the settlement services) in immigration has followed an increasingly more influential and assertive private sector, which has become a pivotal player in advising and articulating government policy. As a result, policy makers are favouring a two-tiered/segmented (im)migration regime, whereby the entry of skilled workers is facilitated and the entry of unskilled workers is allowed only under restricted and substandard conditions. The convergence of private sector interests with policy maker's power to legislate and implement immigration policy is evidenced through the TFWP's LSPP cost-saving measures that include decentralizing programs and, increasingly, devolving responsibility to the private sector and to the migrant.

According to Dobrowolsky (2011), the state filters out the "ideal migrant" and the "ideal citizen" through neoliberal policies that weigh each migrant's short and long-term potential capital contributions. Furthermore, she goes on to argue, "social capital can be a consideration, but it is capital of the hard cash/direct investment variety, and education and skills that come with 'human capital' that constitute the main thrust of contemporary immigration policy" (113). As a result, the political ideology in favour of the 
normalization of a dual segmented (im)migration system has been legally embedded into the functioning of the Canadian economy and society.

Decoupling migrants from access to citizenship, and ultimately membership rights, serves as a way to discipline people and workers. Citizenship, in this case, functions as a key method of distinction to strategically divide and control the global workforce (Bauder 2008, 316). Walia (2010) argues that global capital does not aim at the complete elimination of national borders; rather, it works in partnership with the state to strategically construct border regimes to legalise and regulate different permanent and temporary statuses to benefit organized capital's interests. The role of the state, he maintains, "remains pivotal in a globalised economy, providing the principal means for disciplining the workforce" (73).

The recent (2002) implementation of the TFWP's LSPP is the newest manifestation of Canada's shift in immigration policy direction. The LSPP amplifies the neoliberal tenets previously projected through the NIEAP and SAWP, which aim at reducing the welfare state's exposure to immigration expenditures, to new-untouched industrial sectors. The current government has dramatically increased the size and breadth of the program's impact on the Canadian labour market. Consequently, this expansion has left large swaths of migrants at the margins of socio-economic development and membership rights.

Concomitantly, second-tier migrants are denied certain labour market rights and entitlements, while the first-tier enjoys a variety of rights and entitlements, the most significant one being access to permanent residence (Sharma 2006, 97). Normalization of a two-tiered immigration system, as outlined above, is corollary to broader neoliberal 
practices and ideologies espoused by post-industrial countries - including Canada. Accompanying the expansion of the LSPP is the devolution of immigration to non-state actors. Organizations or agencies like Workpermit.ca or WorkVantage are performing (outsourcing) the administrative functions of the immigration process (Hennebry 2010, 66), and in the process reducing the government's responsibility for the costs this process entails. Henerby (2010) argues the lack of coherence across departments, levels of government, and these new non-state actors in the administration and management of immigration inhibit the TFWP's success. In next section, the paper will illustrate the lowhigh skill dichotomy that characterizes the TFWP's LSPP exclusionary/inclusionary nature.

\section{Exclusion and Inclusion of Low-High Skilled Migrants}

This section will analyze the implicit and explicit exclusionary policies the Canadian government has codified into the TFWP's LSPP. Being cognizant of the plethora of difficulties encountered in the TFWP, this section will highlight the most salient problems affecting LSPP migrants, and not pursue details regarding the auxiliary problems that result from the most salient points. According to a Statistics Canada report by Derrick Thomas (2010), about $60 \%$ of temporary foreign workers with the right to work in Canada between 2006 and 2008 were restricted in some way concerning their relationship to the location of employment, the employer they could work for, and occupation they could be classified as. This statistic clearly illustrates the problems the TFWP's restrictive regulations/work permit create. The result is that large portion of 
temporary foreign workers are explicitly positioned in precarious labour relations circumstances from the get go. To articulate LSPP migrants' vulnerable status, this analysis will draw on Goldring et al. (2009) concept of 'precarious legal status' to illustrate how the Canadian TFWP's two-tiered immigration regime systematically marginalizes the second tier. In the view of Goldring et al. (2009):

Precarious status is marked by the absence of any of the following elements normally associated with permanent residence (and citizenship) in Canada: (1) work authorization, (2) the right to remain permanently in the country (residence permit), (3) not depending on a third party for one's right to be in Canada (such as a sponsoring spouse or employer), and (4) social citizenship rights available to permanent residents (e.g. public education and public health coverage). (240)

The majority of foreign workers brought in through the LSPP are susceptible to high levels of precariousness in all of the four elements mentioned above. However, the first and second are the most crucial as they determine the degree of vulnerability the third and fourth elements will have on migrants. This section will demonstrate that LSPP migrants are consistently being exposed to various degrees of precariousness, through the corrosive restrictions inherent to the TFWP. Goldring's et al. (2009) precarious status concept is concomitant of the neoliberal direction Canada has taken. As mentioned in the previous section, Ottawa, through the TFWP has attempted to curb the overall number of permanent immigrants allowed to enter the country, and simultaneously reduced its responsibility to provide immigration settlement and administrative services (245). This when combined with the liberalization of trade and capital flows, results in the commodification of migrants into unit of labour that can be deployed by employers to participate in the labour markets of post-industrial countries. In order for this process to 
occur, the Canadian state must convince employers that legislation and regulations are in place to discipline the migrant workforce into submission. The TFWP's restrictive work permits and rules provide the 'precarious legal status' necessary to convince both employers to participate in this process.

Complicating the intricacies of Canadian immigration, the Constitution Act (1867) stipulates immigration is a matter of shared federal-provincial jurisdiction (Nakache \& Kinoshita 2010). This has serious implications for the TFWP. On the one hand, the federal government creates and enforces laws pertaining to "aliens," "unemployment insurance" and "criminal law." On the other hand, the provinces create and enforce "social rights" legislation - that is, workers' rights, health care, education and housing. In essence, Ottawa regulates the entry and stay of temporary workers, leaving the provinces to safeguard workers' labour and healthcare rights (Fudge 2011, 28). The creation of the LSPP in 2002 and its subsequent modifications in $2007^{15}$ have exposed various gaps linked to this project's employer driven tenets (Nakache \& Kinoshita 2010). Restrictions engendered by this jurisdictional duality limits both provincial and federal governments abilities to resolve the problems that arise from espousing restrictive temporary migrant regimes, which in many cases expose temporary foreign workers to precarious working conditions.

Through the TFWP's LSPP, the government outsources the immigration and settlement program to the private sphere. The accompanying proliferation of unregulated

${ }^{15}$ Modifications, which were especially driven by Alberta's oil and gas and British Columbia and Ontario's construction sectors, made the program more attractive to employers by extending work permits and introducing an Expedited Labour Market Opinion. 
recruitment agencies (non-state actors) like Workpermit.ca or WorkVantage that are filling the administrative gaps is evidence of the government's retreat from full status immigration regimes (Hennebry 2010, 66). As a result, unscrupulous recruiters have misinformed, exaggerated remuneration, charged excessive recruitment fees, and provided incorrect information about permanent residency attainment (Tomie 2010, 104). Evidently, the government's retreat from the immigration process, via the TFWP's LSPP, manifests itself through the exploitation and deception of migrants from the get go.

From the outset LSPP migrants are disadvantaged and precariously positioned vis-à-vis skilled migrants. They do not have the same labour market mobility as skilled and permanent (im)migrants have. In fact, LSPP migrants are tied to their employer through a work permit and restricted from working for anyone else (Thomas 2010). This is problematic, because LSPP migrants are susceptible to volatile economic and labour market cycles. What is more, they are explicitly disadvantaged vis-à-vis skilled migrants or local workers, as they are prevented from mitigating their economic losses (by securing new employment tenure) and accessing social safety nets ${ }^{16}$. If LSPP migrants lose their jobs or are laid off, they are permitted to remain in the country for the remainder of their work permit, on the condition that they can support themselves; however, if they cannot meet this condition, migrants are required to return home - even

\footnotetext{
${ }^{16}$ Temporary foreign workers' "temporary/employer-specific status" embedded in the unique work permit stipulations, prevents foreign workers from accessing employment insurance (EI) when they have been laid off or have lost their jobs for other reasons beyond their control. The work permit essentially restricts them from being "available to work" for other employers (Nakache \& Kinoshita 2010, 19).
} 
if their permit has not expired, so as to comply with visa regulations (Nakache \& Kinoshita 2010, 18).

Compounding these precarious conditions, the legal mechanisms within the complicated TFWP are not conducive to switching or finding a new job. HRSDC protocol requires that LSPP migrants find a new employer seeking an employee and has either a positive or neutral labour market opinion ${ }^{17}(\mathrm{LMO})-$ or is willing to apply for one. This is usually quite difficult because employers, in order to secure authorization to import temporary foreign workers, must apply for LMOs through HRSDC ahead of time. As a result, the likeliness that other employers would have extra positive or neutral LMOs is unlikely.

The Standing Committee on Citizenship and Immigration's (2009) report argues LSPP temporary foreign workers' already disadvantaged socio-economic position vis-àvis skilled temporary foreign workers, coupled with the LMO's lengthy transition periods mechanism (anywhere from a few weeks to a few months), further marginalizes temporary foreign workers into precarious positions and situations (Tilson 2009, 24). As a result, they are excluded from access to social safety nets, and are vulnerable to events outside their sphere of influence - i.e. economic cycles, volatile labour market conditions,

${ }^{17}$ This process assesses and determines the overall benefit of the procurement of temporary foreign workers on a respective Canadian labour market. It 1)examines the efforts the employer made to recruit and/or train willing and available Canadian citizens/permanent residents; 2) examines whether or not the wages the employer offers are consistent with the prevailing wage rate paid to Canadians in the same occupation in the region; 3) assesses whether or not the working conditions for the occupation meet the current provincial labour market standards; and 4) evaluates the potential benefits that hiring a foreign worker might bring to the Canadian labour market, such as the creation of new jobs or the transfer of skills and knowledge (CIC 2010b). 
abusive employers etc. Ultimately, these conditions can and are already pushing unskilled workers into a precarious legal status, in which they accept work in an informal economy potentially under more and more vulnerable conditions; and are explicitly excluded from basic social services (Contenta and Monsebraaten 2009).

The very nature of temporary foreign workers' temporary status, which is dependent on their contract and relationship with their employer, leaves most workers quite vulnerable to abuse and exploitation. Given that the enforcement of temporary foreign worker's rights is complaint-driven, there is an increased danger and tendency that employers will not adhere to provincial employment standards, and/or violate contractual commitments stipulated in their LMOs. Fear of deportation significantly erodes complaint-driven protection regime's effectiveness at preventing employer exploitation. Most foreign workers, given their precarious status that ties them to their work permit, prefer not to file complaints against employers' violations, due in part to pervasive unchecked employer reprisals (Depatie-Pelletier 2011). With reference to the "equal access" to wages and working rights/conditions the provinces claim they provide temporary foreign workers, Gomez (2011) argues, "even if they [temporary foreign workers] are subject to the same labour standards as Canadians, foreign workers' fear of employer retaliation leading to layoff and loss of status deters them from asserting their rights" (4). Whilst not all employers exploit their temporary foreign workers, the structural gaps inherent in the LSPP's restrictive work permit, coupled with inept complaint-driven enforcement mechanisms, are not conducive to safeguarding temporary foreign workers' “equal access” to provincial rights. 
Finally, and definitely the most salient issue surrounding the TFWP's low and high skill dichotomy, is temporary foreign workers' access to pathways citizenship. On the one hand, skilled temporary foreign workers are eligible to apply for permanent residence through the Provincial Nominee Program (PNP), Federal Skilled Worker Program (FSWP) or the new Canadian Experience Class ${ }^{18}$ (CEC). What is more, they are permitted to bring their spouses into the country while they are employed, without any work permit restrictions being placed on them or the spouse. On the other hand, and in stark contrast to the skilled migrants, unskilled migrants are not only faced with numerous barriers to accessing pathways to permanent residence and social services, they are also implicitly restricted from bringing their spouses to Canada (Nakache \& Kinoshita 2010, 32). LSPP migrants' only pathway to permanent residence and by extension, citizenship, is the PNP; they are restricted from applying for permanent resident status through the CEC. However, with the exception of Manitoba and Saskatchewan's PNPs, this pathway has not significantly provided LSPP migrants access to permanent residence or citizenship (Austin \& Bauder 2010; Macleod 2008).

In summary, the government's retreat from the immigration and settlement process, via the TFWP, coupled with discriminatory immigration laws embedded in the LSPP, provides the basis for the majority of problems surrounding the TFWP's acceleration and expansion, via the LSPP, into new labour sectors of economy. This paper acknowledges that there are many other issues exacerbating LSPP migrants'

\footnotetext{
${ }^{18}$ This class is designed to allow high skilled migrants and international students access to permanent residence. To be eligible both migrant groups must have at least one year of Canadian work experience (CIC 2008).
} 
welfare: complaint-driven protection regimes, misinformation of rights and access to social services, language barriers, etc. However, these additional issues all stem from the problems outlined above. Given this paper's scope to analyze the core problem - having access to permanent residence and citizenship, and by extension equal membership rights to citizens and permanent immigrants - it will not pursue these other auxiliary issues. The next section will discuss the state, and its management of citizenship principles to legitimize and naturalize a two-tiered/segmented immigration system, despite having universally equitable legislation in place.

\section{Citizenship and the Segmentation of the Labour Market}

This section will shift the paper's attention to the role citizenship plays in creating a segmented labour market. Citizenship plays a pivotal role, in that it is the mechanism the state uses to either include or exclude (im)migrants. Without this mechanism, it would be more difficult to develop and maintain a segmented labour market. In addition, I will juxtapose the contradictive nature of the TFWP's LSPP against Canada's self touted liberal democratic values.

Given the contemporary importance attached to permanent status and ultimately the eventual acquisition of citizenship to access rights and entitlements, it is necessary to examine the principles grounding pathways to such acquisition. The power of state sovereignty to designate citizenship rights within its territory has been crucial to the institutionalization of segmented immigration regimes (Castles 2005, 208). Within this 
power hierarchy, parliamentarians and - increasingly - the executive possess the power to determine the conditions migrants must abide by when entering Canada.

There are mainly two different approaches to citizenship. First, jus sanguinis (Latin: right of blood) is rooted in ancestral lineage, whereby emigrants retain their nationality and transmit it to their children - this facilitates closer ties with the origin country (Wayland 2006). Germany is a prominent example of a country that espouses the jus sanguinis principle, which essentially restricts citizenship to descendants from previous citizens, and thus does not facilitate immigration. Second, jus soli (Latin: right of the soil) is based on birthright citizenship. The children of immigrants have an automatic right to citizenship. This is typically the norm in classic countries of immigration like Canada (Wayland 2006).

Both principles are employed with varying degrees of rigidity to determine citizenship in most countries around the world. However, a third principle also exists, jus domicile (Latin: right to habitation), but is not commonly used. This principle postulates that people inhabiting a community, whether they fall under the principles of jus soli or jus sanguinis (or not), should gain entitlement to citizenship through residence in the territory of the inhabited country (Castles 2000, 167). Essentially, jus domicile fills the gap created by jus soli and sanguinis, which excludes migrants who were neither born in the receiving country nor born from a citizen of the respective territory. As Austin and Bauder (2010) point out, Canada, to a certain extent already subscribes to this principle, in that it grants immigrants permanent residence, which (as previously mentioned) affords them all the rights and entitlements citizens receive with the exception of the 
franchise (6). However, given the evident segmented nature of the labour market, this access to jus domicile is not equitably applied to all migrants.

To explain the dichotomous application of temporary and permanent (im)migrants' status in Canada, it is necessary to examine the state. The emergence of the nation-state from the 1648 Treaty of Westphalia, has led to the broad acceptance of the concept of state sovereignty providing the ability to the state to govern everything and everyone within the borders of its respective territory (Simmons 2010, 21). The nationstate system has been the dominant force in steering the economy and creating and enforcing laws between the $18^{\text {th }}$ and $20^{\text {th }}$ centuries (Wallerstein 2000, 21).

In Canada, the state - as mentioned earlier - has undergone numerous changes since the rise of the welfare state, most notably the neoliberalization of social policy (Harder 2001, 120). This trend is not exclusive to Canada. In fact, it is a general trend occurring throughout the West (McBride 2005, 96). The dismantling of the welfare state, coupled with organized capital's new found economic/political power to erode state sovereignty, has had a dramatic impact on how countries - like Canada - design and implement their immigration policies. The result has been an ideological shift on the part of policy makers to favour organized capital (by facilitating the entry of highly and low skilled temporary migrants) and limit state exposure to increased budgetary burdens brought on from new (im)migrant arrivals. This shift is problematic, because it contradicts the self-proclaimed principles of social justice Canada so proudly touts (embedded in the Canadian Charter of Rights and Freedoms) and has upheld for a large part of the last half-century. 
The enactment of the Canadian Charter of Rights and Freedoms in 1982 provides significant rights to non-citizens. Yet, the permanent/temporary two-tiered division of (im)migrants arriving in Canada continues to expedite two different sets of rights and entitlements. Section 15 (1) of the Charter, which applies to any and every individual within Canadian territory - including non-citizens - stipulates:

Every individual is equal before and under the law and has the right to equal protection and equal benefit of the law without discrimination and, in particular, without discrimination based on race, national or ethnic origin, colour, religion, sex, age or mental or physical disability. (CCORAF 1982)

However, Section 1 of the Charter stipulates that the guaranteed rights and freedoms are subject "to such reasonable limits prescribed by law as can be demonstrably justified in a free and democratic society" (CCORAF 1982). As Galloway (2001) points out, this qualifying section permits governments to enact legislation that restricts identity rights. He goes on to note that courts have imposed heavy demands on governments attempting to restrict identity rights because these rights are regarded as fundamental elements of "human dignity or the moral status of an individual" (177). If what Galloway (2001) asserts has truly been the case, why is it then that LSPP migrants are not protected by the courts from the government's inequitable restrictions (Keung 2012; Walton2012; Turner2012)? Evidently, the courts only constrain the government to a certain point. In the end, it evident that the state holds the power to establish laws and policies that it believes are in the national interest - i.e. implementing exploitative two-tiered/segmented temporary immigration regimes.

In order to understand why the two-tiered TFWP continues to explicitly exclude 
LSPP migrants from the rights enjoyed by permanent immigrants, it is necessary to look at how the power of the state, to designate citizenship rights within its territory, has been crucial to the institutionalization of the TFWP's two-tiered immigration regime. As Macklin (2010) points out, citizenship as a legal status "is the formal status of membership in the state, or nationality as understood in international law, and typically encompasses the right to enter and to remain in the territory, access to assistance and diplomatic protection, and the franchise" (cited in Fudge 2011, 11). Essentially, the state uses sovereignty to designate who can become a citizen, permanent immigrant, and who will remain non-immigrants or non-citizens within its territorial boundaries. As Sharma (2006) points out, the implementation of precarious temporary migration regimes "were organized through the internationally recognized sovereign right of national states to deny rights and entitlements to those named as non-citizens and non-permanent residents" (99).

Canada uses citizenship as an ordering principle to regulate labour markets by delineating the level of access workers receive to the labour market - most specifically the secondary segment (Bauder 2008, 317). This "partial citizenship" or "non-status" permits the state to exclude migrants from its territory, and from accessing rights and entitlements that migrants may accrue while working in the respective state's territory (Fudge 2011). As Macklin (2010) states: "rather than pose the question "who is the citizen?,' I begin by asking, 'who is the citizen's Other?,' partly as a means of surfacing what we mean by citizenship through thinking about who we designate as its alterity" (336). Immigration law in this case is not just about who is, and who is not allowed to enter the country, its also about the structural conditions of precariousness (or not) the 
state assigns each individual allowed to enter the state's territory (Fudge 2011, 11). Marsden (2011) rightly points out, "the basic dilemma of liberalism is created within migration law and maintained by courts whose sovereignty is based on the absolute right of a state to choose its members on a discretionary basis" (61). Sharma believes that Canada's ideological framework - of assigning privilege or non-status to migrants legitimizes and naturalizes the exploitation of people as indentured labour in Canada (98).

While the state's legal power (formally) plays an important role in the production process of domestic social order (in that it installs and enforces corrosive social order legislation and parameters), it is also the informal cultural processes of social ordering and reproduction that completely crystalizes the naturalization of a segmented labour market through citizenship (Bauder 2008, 316). Non-migrants strategically imagine and generate different conceptions of citizenship/cultural capital that are characteristic of the dominant population, which in turn produce and reproduce labour market inequality (Sharma 2006; Bauder 2008). According to Bauder (2008), “non-migrants often express identities of belonging through citizenship" (324). Intrinsically, then, the combination of formal (legal distinction) and informal (cultural distinction) processes of citizenship production act as a mechanism to regulate labour markets through varying degrees of inclusion or exclusion.

Conversely then, Canada as a self-proclaimed liberal democracy is not so liberal or democratic after all. The creation of temporary migrant regimes that generate differing classes of people, who live and work in Canada just like any other permanent resident or citizen and, who are restricted from accessing all the rights and entitlements the rest of 
the population receive, does not sound exactly liberal or democratic. As Westlake (2010) points out, "it is clear that freedom to choose where one wants to work is a right reserved for citizens but also, that such a statement is not openly acknowledged as contradictory, is evidence of how citizenship naturalizes the existence of two sets of rights."

The very fact that LSPP migrants are tied to restrictive work permits, contradicts the grounding foundations of a capitalist liberal democratic state like Canada. According to Marsden (2011), "[it] is problematic within a liberal democracy because there appears to be no possible justification for their [non-status migrants] exclusion that is consistent with liberal values" (61). As a consequence, social, political, and economic marginalization of LSPP migrants produces varying hierarchies of rights and membership within Canada (Goldring et al. 2009, 247). If capital, goods, and people are supposed to freely circulate, as liberal free market principles generally posit, how can the LSPP's restrictive employer bound work permit be compatible with a "liberal democratic" country like Canada?

Not surprisingly, the division of permanent and temporary (im)migrants through the TFWP - which actually contradicts democratic values - works in tandem with organized capital. Having an increasingly large portion of the workforce tied and restricted to specific employers, enhances organized capital's control over the labour market (Sharma 2006). The employer driven process inherent in the TFWP, provides organized capital with a stable, flexible, subservient, and predictable workforce. As Marsden (2011) points out, "workers without membership rights are workers who are more vulnerable to exploitation, less likely to demand improvements in wage or working conditions, and without mobility — all of which makes them more profitable for 
employers" (62). For organized capital, the TFWP is heaven on earth; it allows employer's to exploit LSPP migrants without being liable to the plethora of laws and regulations protecting permanent immigrants and citizens.

Much of the debate concerning unskilled migrants has primarily revolved around improving the restrictive work permit and, to a lesser extent providing other protections to the regulatory gaps that emerged as a result of the government's neoliberal retreat from some dimensions of the immigration and settlement system. On the one hand, the government argues that expanding the work permits "with a view to improving temporary foreign workers mobility would undermine initiatives recently introduced or underway to better monitor employers' compliance with their commitments under the TFWP, and hence, better protect TFWs" (Canada 2009). In addition, the current Harper government does not believe there is an apparent need for a broad-based long-term policy to provide unskilled workers with permanent residence (Canada 2009).

On the other hand, policy analysts argue that following the 2009 Standing Committee on Citizenship and Immigration report's (on Temporary Foreign Workers and Non-status Workers) recommendations to expand LSPP migrants' labour market mobility, by reducing work permit employer bound restrictions, in conjunction with more robust government protection regimes are the key to mitigating the TFWP's problems. Furthermore, analysts believe the lack of access to permanent status and settlement and language services will drive many migrants to remain in Canada underground and/or undocumented (Alboim and Maytree 2009, 49). The effects of not properly addressing the precariousness built into Canada's two-tiered immigration regime will be severe. In following section, I will discuss the structural role migrant labour plays in Canada. 


\section{How Migrant Labour is Seen as a Structural Necessity}

Typically, (im)migration to post-industrial countries has mirrored the business cycle, increasing inflows in periods of economic expansion and decreasing inflows in periods of contraction. However, according to Bauder (2006), business cycles and labour market fluctuations in post-industrial countries no longer affect international migration flows; instead, it is international migration that regulates economies (4), which in turn leaves them dependent on (im)migrant labour. Canada is no exception. As mentioned above, the crisis of the welfare state, declining birthrates/population aging, and the globalization of manufacturing have resulted in the restructuring and dual segmentation of Canada's labour market. Concomitantly then, how can the welfare state and high wages be maintained in light of rapid and sustained deindustrialization?

The deployment of an exploitable migrant workforce to fill positions in the secondary labour segment provides post-industrial countries with a solution to their competitiveness conundrum. Migrant labour that is more "flexible"/employer-driven has become policy (Siemiatycki 2010, 61) and a structural necessity (Cohen 1987). During the 2008 economic crisis, the flight of manufacturing (in the tradable sector) was mitigated by the rise of the resource industry and by extension the non-tradable sectors (Beine, Coulombe, \& Vermeulen 2012, 5). Proponents of equilibrium theory would argue that the rebalancing from tradable to non-tradable sectors would see wage levels in the middle segment be sustained or even increased, due to labour shortages and the increased demand for labour that accompanies the boom in the resource sector (Pritchett 2006). 
However, the importation of temporary foreign workers to fill these labour shortages interrupts this process, resulting in the stagnation of wages, labour conditions and benefits (Gross 2011, 533).

Gross' 2010 study indicates that increasing the scope of the LSPP has adverse effects on Canadian unemployment rates. Her findings show increasing the size of the labour market through the TFWP's LSSP decreases the propensity for employers to increase wages in the sectors experiencing shortages; simultaneously, unemployed Canadians are not incentivized to move across the country to fill the labour shortages. Gorss (2010) cites the enactment of E-LMO (2007) initiative, which decreased the period employers had to advertise the job opening in Canada and increased the period in which temporary foreign workers could work in the country from one to two years, as an example of how the government uses such immigration policy to reduce the cost of bringing in temporary foreign workers. The use of this initiative made it cheaper to bring in temporary foreign workers than Canadian workers in other provinces. That is, by increasing the period temporary foreign workers are allowed to work in Canada from one to two years, the government cuts the employers recruitment costs (Gross 2010,110). As Gross points out, "if this differential is not great enough to induce employers to raise wages to attract resident workers from other regions, and if it also decreased, it is possible that the TFWP would contribute to maintaining important regional differences in unemployment" (110). Abstaining from this interruption process would raise the cost of living for the primary segment, lower employers' profits/exploitative capacity of temporary foreign workers, and render Canada less competitive vis-à-vis global competitors. 
This immense pressure to compete with wages and labour conditions in the Global South has displaced resident workers from well-paying jobs in the middle segment to the secondary segment, where the incorporation of temporary foreign workers conditions their demotion to "more competitive" terms of labour relations (Bagchi 2008, 205). Simultaneously, the temporary foreign workers - who are arguably brought in to discipline the targeted labour sector - are exposed to precarious working conditions. Even unemployed residents and (im)migrants are integrated into the labour force, in the sense that they augment labour supply and by extension wage structures and labour conditions (Bauder 2006, 9). Furthermore, the work permit's extension, which allows temporary foreign workers to have two-year visas and extend their stay to four years (Preibisch 2011, 70), indicates the structural role migrant labour plays in sustaining and disciplining the Canadian labour market.

In this new (im)migration paradigm, it is competition strategies and not nation building strategies that inform and articulate immigration policy and, ultimately, the labour market. To facilitate the importation of temporary foreign workers into newuntouched areas of the secondary segment, the state in partnership with organized capital have designed and organized policies to "fast track" migrant inflows. The North American Free Trade Agreement and Security and Prosperity Partnership have been designed to "maximize" continental economic competitiveness in the face of growing exports and competition from India and China (Walia 2010, 78). In Canada's case, the TFWP's LSPP appears to be the centrepiece for the development of a competitive/"flexible" labour market. To accelerate and expand the size, intensity and impact of the LSPP, the federal-provincial governments implemented three initiatives: 
the identification of "Regional Occupations Under Pressure" (ROUP), occupations under pressures (OUP), the "Expedited Labour Market Opinion" (E-LMO), and most recently (although not yet activated in the LSPP) the "Accelerated Labour Market Opinion" (ALMO). The first two initiatives were designed to augment the LSPP. The third initiative at the moment (2012) - only applies to skilled temporary foreign workers and is also designed to increase the scope of the TFWP, ultimately favouring employer interests. The timing of the initiatives has been reactionary in nature, as they are designed to mitigate immediate labour shortages and not plan for future nation building.

The chronological progression of these initiatives has been in three steps. First, the ROUP implemented December 2006, which streamlined the application process (reduced the period employers had to advertise a job before applying for a LMO) and extended the work permit period from 12 to 24 months, fast-tracked temporary foreign workers to fill positions experiencing labour shortages in Alberta, British Columbia and Ontario (CIC 2007). This jump-started the LSPP and extended the time temporary foreign workers were permitted to stay in the country. Shortly after, the occupations under pressures (OUP) were extended to other provinces, which also espoused the same rules and mechanisms of the RUOP.

Second, in September of 2007, HRSDC implemented the E-LMO Pilot Project in Alberta and B.C., which essentially "fast-tracks" temporary foreign workers into 33 highdemand occupations in both respective provinces ${ }^{19}$ (CIC 2010c). The E-LMO was ended

${ }^{19}$ Those in demand occupations included: carpenters, crane operators, construction labourers, hotel front desk clerks, food and beverage servers, food counter attendants, 
by HRSDC on April 15, 2010. CIC (2010c) claims this initiative helped eliminate "LMO processing backlogs in Alberta and British Columbia and effectively tested new approaches to assessing employer compliance.”

Third, on April 25, 2012 HRSDC implemented the A-LMO, which reduces the paper work required from employers with a strong track record in the TFWP, reduces the time HRSDC takes to issue LMOs for skilled temporary foreign workers to 10 business days, and allows employers to pay temporary foreign workers $15 \%$ below the average wage for an occupation in a specific region, to "ensure that the TFWP supports [Canada's] economic recovery and effectively responds to local labour market demands" (HRSDC 2012a).

The Three initiatives have made it significantly cheaper to hire temporary foreign workers vis-à-vis resident workers (Gross 2010,110) and made it easier for employers to cite labour shortages to accelerate temporary foreign worker inflows into previously untouched labour sectors (Preibisch 2011, 78). These initiatives have two major effects. First, they organize and facilitate the terms and conditions by which temporary foreign workers are brought into the country. Second, they concomitantly set new parameters and conditions on displaced resident workers demoted to the secondary labour segment. Essentially, capital's continental synergy enables it to be a prominent player in the design and implementation of temporary migrant regimes by informing the state on how to best "meet" labour shortages and "compete globally." Further, the E-LMO and OUP allow it to circumvent labour market protections or "checks and balances" that were originally

food service supervisors, registered nurses, dental technicians, pharmacists, snowboard and ski instructors, retail sales persons and sales clerks (CIC 2010c). 
embedded within legislation to protect organized labour in the past.

The A-LMO - the most recent of these initiatives - will have the most impact especially if its rules are eventually applied to the LSPP. Embedding rules that create a two-tiered wage structure (employers are allowed to pay temporary foreign workers 15\% less than Canadian workers) and increase the speed with which temporary foreign workers can be brought in to the country (10 working days) is dangerous and shortsighted. Tom Sigurdson, executive director of the B.C. and Yukon Territory Building and Construction Trades Council, and Nancy Furlong, secretary treasurer of the Alberta Federation of Labour (AFL) both view this expansion of the TFWP and implementation of the A-LMO as a method to reduce wages by increasing the supply of cheap exploitable labour (Gilbert 2012). Further, they both believe the reduction in both wages and the processing time of temporary foreign workers will exacerbate the unemployment problem in Canada and open the door to further abuse of already vulnerable workers (Gilbert 2012). By normalizing these initiatives through government mechanisms and policy, temporary foreign workers become a permanent fixture within the functioning of Canada's labour market. Although HRSDC is mandated by law to consult with unions when employers want to import temporary foreign workers, labour unions have had limited to no participation in this process. In fact, consultation with unions have been limited and inconsistent since 2003, which coincides with the implementation and expansion of the TFWP into untouched labour sectors through the LSPP in 2002 (Valiani 2007, 3).

In Canada, migrant labour is seen as a structural necessity for global competitiveness. The watering down of wages, labour rights, and benefits in new labour 
sectors produces and expands the stock of unstable jobs and working conditions. Many scholars and policy analysts (Sharma 2006; Preibisch 2011; Valiani 2007; Nakache and Kinoshita 2010) believe this creation and expansion of unstable jobs into previously untouched labour sectors is an attempt on the part of post-industrial countries to remain competitive. Marsden (2011) believes the increased proportion or temporary foreign workers vis-à-vis immigrants, and even increased number of unskilled vis-à-vis skilled temporary foreign workers, within the TFWP is evidence of Canada's dependence on this new (im)migration paradigm (50). As mentioned above, amended regulations, which allow temporary foreign workers to stay longer, signify the intension on the part of the government to expand, rather than reduce the size of the secondary labour segment.

The expansion of the secondary segment, through the TFWP, has benefited the primary segment's job security and quality of life; the latter gains increased job security and access to cheaper goods and services produced by the former (Abella 2006, 16). The National Union (2007) maintains that where labour shortages exist, the government should use the immigration system to recruit workers as prospective citizens rather than issuing temporary work permits (2). However, following this advice would prevent organized capital from "remaining competitive," and by extension, remove the state's corrosive "stick" to discipline its labour market in light of the pressures created by globalization. Moreover, the state's use of temporary migrant regimes enables the replenishment and maintenance of labour markets to meet industrial capacity without exposing itself to the social costs (both financial and political) associated with full-status immigrants, all of which has engrained "flexible"/subservient labour as a permanent fixture in Canada's socio-economic development. 


\section{Implications of a Continued Expansion of the TFWP's LSPP}

This paper has outlined many of the issues arising from the acceleration and expansion of the TFWP's LSPP. In an attempt to adjust to domestic and international changes in demographics and economics, the federal and provincial governments have managed to quickly leverage the TFWP through the LSPP in the name of meeting acute labour shortages created by both demographic pressures and a shift in the economy from manufacturing (tradable sectors) to resource extraction (non-tradable sectors). In the short-term, the implications of these changes to (im)migration policy and by extension labour and economic policy, have benefitted and hindered different societal actors.

On the one hand, the government's immigration policy tool - in the form of ministerial instructions which permits the executive to quickly change aspects of (im)migration policy without parliamentary oversight (Picot \& Sweetman 2012) - has benefited employers and the private sector significantly. These ministerial instructions have facilitated the creation of initiatives that accelerate and ease the ways through which employers can import temporary foreign workers to quickly fill labour shortages in a short period of time vis-à-vis the FSWP. On the other hand, resident Canadian workers in non-tradable industries have seen their wages, work conditions, and benefits decline (Gross 2010). The confluence of the TFWP's LSPP restrictive conditions on temporary foreign workers and its corrosive effects on Canadian workers' livelihoods creates the perfect conditions for exploitation to entrench. In this process, many documented cases of abuse of temporary foreign workers by employers highlight the problems in the TFWP's 
LSPP regulatory framework and enforcement system.

As previously noted in the literature, the short-term implications are apparent and amply discussed (Nakache \& Kinoshita 2010; Alboim and Maytree 2009; Bauder 2006; Preibisch 2011). Before illustrating the long-term implications and some follow up recommendations, I will summarize what many scholars and policy analysts have already outlined and advocated: temporary foreign workers are not provided enough support or protection to file complaints against their employers. Exploitation due to the LSPP restrictive work permit, which bonds temporary foreign workers to their employer, is ubiquitous. As a result, in many cases employers underpay workers, charge them illegal fees, and abuse their temporary foreign workers' labour rights. Vanderklippe (2012) goes as far as arguing, "employers no longer fear being caught for underpaying workers, charging them illegal fees or doing an insufficient job of canvassing for Canadian labour."

The general belief in the literature is that the TFWP should be abolished in light of all the problems it creates. However, as ideal as this solution would be, it is not realistic. There will be seasonal labour shortages, given Canada's climate and economy, that will produce a need for temporary work. The key is determining how big this section really is. As this paper has outlined, employers are clearly using the TFWP to fill permanent labour shortages. Fariborz Birjandian, executive director of the Calgary Catholic Immigration Society, says and asks why the government "ignore[s] the fact that some of these positions people are being hired for are permanent jobs, so why are they not addressing that through an immigration policy?" (Russel 2012). The impetus of my recommendations draws from this train of thought. Preventing government mechanisms 
within HRSDC from blurring these lines in favour of private sector interests is critical. Only once this process has been corrected and streamlined to reflect the legitimate temporary labour shortages, can we begin to start talking about protections for temporary foreign workers.

When HRSDC announced it would be modifying aspects of the TFWP by enacting the A-LMO initiative, it also stated its intention to increase protections for temporary foreign workers. HRDSDC maintains it will closely monitor employer compliance and take action when necessary to protect temporary foreign workers. However, while HRSDC mentions it will strengthen protection for temporary foreign workers through employer compliance reviews, it fails to explicitly identify details (i.e. a budget, regional offices, number of government officers to be assigned to the protection and enforcement of TFWP regulations, etc.) to follow through on its promises. Given the government's poor record in providing adequate enforcement that truly discourages and punishes abusive employers, it is vital Ottawa be clear about how it is going to fund, operationalize, and manage such a system. A TFWP that inherently puts temporary foreign workers at risk, via its restrictive work permit, cannot and will not provide adequate protection for temporary foreign workers. Most of the other problems/implications stem from the work permit's restrictive rules and will be discussed further below.

When Jason Kenney, Minister of Citizenship and Immigration, was asked if he anticipated the number of temporary foreign workers would increase or decrease, he responded, "given the acuteness of the labour shortage, it will probably stay relatively high. I wouldn't be surprised to see some increases" (Friesen 2012). Minister Kenney’s 
response indicates the government foresees further increases to the scope of the TFWP. This - as my paper and implications will illustrate - is inherently problematic. I argue, throughout my recommendations, that the scope of the TFWP needs to be decreased to reflect labour market realities; protect Canadian and temporary foreign workers' wages, working conditions and benefits; and comply with the IRPA's mandate (to use immigration to increase the quality of life of Canadians). Furthermore, accompanying this decrease, an increase in the scope of permanent immigration is necessary to fill the acute permanent labour shortages being experienced, not to mention the second function permanent immigration status plays in protecting immigrants.

While these short-term implications illustrate a worrisome picture about the wellbeing of both resident Canadian workers and temporary foreign workers, it does not, however, inform us on what are the long-term consequences of continuing to accelerate and expand the TFWP's LSPP. The long-term implications of continuing to expand the LSPP are worrisome and multifaceted. Its effect on the Canadian economy will be to incentivize temporary foreign workers' remittances abroad whilst hollowing out swaths of the Canadian middle class (socio-economic polarization). These in turn, will inhibit the economic activity stimulated by the latter's domestic consumption. The erosion of other Canadian training programs is another potential outcome, which would result in the exclusion of many Canadians from the "in demand jobs" of the future. Corollary to such exclusion from future jobs is the possibility that Canadians, who see migrants as increasingly "taking away" such jobs, begin to resent immigration. When the possibility that LSPP temporary foreign workers (who are only permitted to legally work in the 
country for four years), are likely to stay in Canada undocumented is added to this, the socio-economic polarization scenario mentioned earlier will be further exacerbated.

Combined, all these implications have the potential to seriously damage or devalue the "Canada brand," which means that Canada is still considered to be a "destination of choice" by would be immigrants the world over. Below I outline the possible long-term implications of continuing to accelerate and expand the TFWP's LSPP. Following each implication/problem, I will discuss recommendations that might help mitigate the negative impact each implication may have on Canadians and temporary foreign workers.

\section{i. Increased Outflows of Money from Canada}

As Lenard and Straehle (2010) point out, temporary foreign workers are more likely to remit more of their income if there is no possibility of settling permanently. More money/dollars will leave the country in the form of remittances because temporary foreign workers have no reason to spend much or to invest in Canada if they are forced to leave. In the short-term, this process has probably been accelerated given the LSPP's restrictive four-year work permit. The roughly 300,000 temporary foreign workers currently in Canada (CIC 2010) could be investing their income into local and regional economies. In the long-term, as the TFWP accelerates into new industrial sectors, so does the numbers of LSPP migrants. The arithmetic is simple. A larger proportion of temporary foreign workers vis-à-vis immigrants entering Canada will result in increased outflows of money in the form of remittances to sending countries. Given the continued 
growth of the TFWP's LSPP, it is expected that these money outflows will rise proportionately. This is problematic because instead of this money being pumped into the Canadian economy to spur growth and jobs, it is redeployed to carry out those functions in another country. While some advocates - Pritchett (2006); Ruhs and Martin (2008); Lenard and Straehle (2010) - of the use of temporary migrant regimes to achieve development have argued this process of redistribution, through migrant's remittances, is a beneficial to everyone, it is, in fact, inherently problematic, for reasons outlined earlier in the second section of the paper.

Exacerbating the increase of remittances out of Canada further is the restrictive rules of the LSPP's work permit, which implicitly prevents temporary foreign workers from bringing their spouses (Nakache \& Kinoshita 2010; AFL 2012a). The effects of this restriction are twofold. First, it further prevents temporary foreign workers from establishing any "roots" or reasons to invest in the communities they live and work in. Second, it divides the temporary foreign worker's family, which essentially forces the family to divide and remit the main income earner's income. This is very inefficient. It creates the need for the LSPP temporary foreign workers to remit a large portion of his/her income, which leave less to be spent in Canada. Raj Sherman, Alberta Liberal Leader, maintains, "money is often sent back home to support families left behind, meaning that it leaves the Canadian economy" (AFL 2012a). Continuing to expand the LSPP will only increase this phenomenon and essentially act as a tax on regions or communities in which temporary foreign workers live and work in. Enabling temporary foreign workers to access equal rights would benefit not only their own future but also Canada's. 


\section{$\checkmark$ Recommendation}

There are two solutions to this problem. First, regulations discouraging LSPP temporary foreign workers from bringing their spouse with them must be reversed: LSPP temporary foreign workers' spouses must be issued a work permit that allows them to work. Doing so, as outlined above, would benefit not only Canada from a nation building perspective, it would also stimulate the economy of every community containing large contingents of temporary foreign workers. Furthermore, stabilizing family units would encourage migrant families to spend on long-term investment items, such as furniture, appliances, cars, educational equipment etc. all of which would support and create more local jobs.

Second, which is also interconnected with issues relating to access to permanency, the government must eliminate the LSPP's four-year work permit limit and provide LSPP temporary foreign workers access to the CEC or the PNP. Incentivizing LSPP temporary foreign workers to become permanent residents and enabling them to bring their spouses with them will curb money outflows. They will have more reason to stay, establish roots, and invest in their community and future socio-economic development. It is a "win-win-win": Canadian employers benefit from having a more stable/experienced workforce that does not have to be retrained every four years; LSPP temporary foreign workers benefit from being able to reunite their families and from having access to pathways to citizenship, which provides them with stability and social security; and both federal and provincial governments benefit from increased tax revenues, populations growth, and decreased money outflows, which remain in the 
economy and further stimulate regional and sub-regional economic growth.

\section{ii. Decline in Domestic Training and Apprenticeship Programs}

The increased use of the TFWP's LSPP to fill labour shortages created in the new resource extraction (non-tradable) economy, many unions argue, will reduce pressures for the government to fund training and educational programs for Canadian residents. With reference to HRSDC's enactment of the A-LMO initiative, Gil McGowan, president of the Alberta Federation of Labour, believes "[this is] just going to discourage companies from taking on apprentices and training the next generation of tradespeople" (AFL 2012a).

In addition, there is growing concern the federal government's stated intention to reform employment insurance (EI) rules will exacerbate this problem. The government's budget bill, C-38, will remove key sections of the Employment Insurance Act that permits recipients to turn down available jobs if they are not in their field of work or involve poor working conditions (Curry 2012). These reforms combined with the ALMO appear counterintuitive and incoherent from a skills training perspective. Many critics and policy analysts are asking why the government - through the A-LMO - is making it easier and cheaper for employers to use temporary foreign workers, while the unemployment rate remains so high. Continuing to bring temporary foreign workers, which interrupts supply and demand market principles that would incentivize Canadian workers to migrate and fill many of the labour shortages being experienced, will only intensify this problem. 
It is already evident that training of Canadians in the skilled trades and other nonuniversity training programs is insufficient. The OECD and the Innocenti Research Centre (IRC) in Florence have noted that even though Canada is one of the richest countries in the world, "Canada is one of the lowest spenders on skills training and other labour supports" (OECD \& IRC cited in Valiani 2007). Many critics believe the federal government is using the TFWP to mitigate this under investment in skills training. For example, between 2007 and 2011 30\% of all the jobs created in Canada were filled by temporary foreign workers. This is problematic, given that 1.4 million Canadians are unemployed (Gil McGowan AFL 2012a). Valiani (2007) maintains the federal government's devolution of training programs to the provinces and territories has eroded the Interprovincial Standards Red Seal Program (apprenticeship system). This, she argues, is problematic, given the program's importance in helping train Canadians to fill imminent labour shortages (7).

In the long-term, continued expansion of the LSPP could see temporary foreign workers' share of total jobs filled rise further. Moreover, the continued use of the LSPP to meet labour shortages in the new resource (non-tradable) economies would leave Canada dependent on other countries' "excess stock" of workers, training programs, and regulatory norms and standards. Government complacency regarding training and educational programs to meet its domestic labour shortages, in the long-term, could render the country less competitive and desperate. If competition for these migrant workers were to ever spike internationally, Canada might find itself incapable of filling labour shortages through (im)migration. Further, McGowan argues that "[this] short-term fix could lead to a long-term, structural shortage of skilled tradespeople if Canadian 
workers opt for other occupations because of a lack of jobs in industries employing temporary foreign labour" (Russel 2012). As McGown points out, depending on temporary foreign workers to fill short-term labour shortages in the long-term it is problematic. Canada must have a strong skills training system if it wants to remain competitive vis-à-vis its OECD peers. Relying on temporary foreign workers from other countries to fill labour shortages that drive the country's economic growth is dangerous and reckless. If the forecasted increased "peak people" ${ }^{20}$ scenario in which competition for migrants is set to spike is believed, Canada must invest in skills training and not become completely dependent on foreign labour to meet its labour market needs.

\section{- Recommendation}

As mentioned above, Canada is lagging its OECD colleagues in terms of investment and participation/skills training programs. For example, Germany's Alliance for Jobs and Singapore's Critical Enabling Skills Training program train and place 60,000 and 100,000 workers in sectoral industries, respectively (Rowles 2003). Jim Flaherty, Minister of Finance, recently noted that labour shortages will be one of Canada's most salient challenges in the future (Calgary Herald 2012). Yet, the Harper Government is not attempting to invest in training programs that will help alleviate such shortages. It is therefore incumbent upon governments - at all levels - to develop strategies to foster local, regional and national training programs that help mitigate the

${ }^{20}$ Throughout the 21 st century the entire world's population will stop growing, level out, and start falling (Saunders 2012). 
imminent labour shortages of the future. To do so, they must consult with all stakeholders - employers, unions, educational institutions, etc. - to strategically identify which occupations will experience the greatest shortages and provide funds and incentives for Canadians to be trained to fill the expected labour deficits. The potential benefits of increasing the scope of skills training are significant for the workers. According to Rowles (2003), these include, "not only wage gains, but job satisfaction, increased job performance, and an enhanced sense of security that results from workers' awareness of increased employability" (3). In addition, there are very significant benefits for the economy in general, as mentioned above.

With regards to the government's plans to reform EI, a coherent and intuitive strategy must be developed. Forcing Canadians receiving EI to take unskilled jobs that temporary foreign workers have recently been filling could drive down wages in sectors that would have otherwise had to increased wages to attract workers. It also reduces pressures on governments to train or retrain Canadians receiving EI for industries experiencing labour shortages. This policy direction must be reversed. On the one hand, the federal government, through the A-LMO, has implemented rules that allow employers to pay temporary foreign workers $15 \%$ less than Canadians. This is counterproductive and will only drive down wages for everyone and disincentivize Canadians from wanting to train in that specific industry in the long-term. Therefore, it is necessary to eliminate the A-LMO initiative so as to allow market principles of supply and demand do their job (i.e. raise wages and incentives/attract Canadian to such fields).

On the other hand, the federal government is changing EI rules to prevent Canadians receiving EI from being able to decline certain jobs, even though the jobs may 
not match the workers' skill sets. If the government wants to force Canadians receiving EI to take jobs in industries experiencing labour shortages, it must put forth a skills training program to place these Canadians in the industries of the future that will provide decent living standards - and not erode them. Combined, these approaches would allow the supply and demand principle to raise wages and incentivize Canadians receiving EI to be trained or retrained and migrate to regions experiencing labour shortages. McGowan maintains, "policy-makers should be looking first at finding ways of opening doors for unemployed workers here in Canada" (Russel 2012). Views in some areas of the private sector also echo this sentiment: Rod Ruston, CEO of North American Construction, believes the government must expand the number of seats at technical colleges to train young tradespeople, provide tax deductions for travel and relocation costs for workers moving across the country for jobs, and limit government restrictions on which unions and companies can do business to expand the Canadian labour pool. Moreover, he argues, “you wouldn't need as many foreign workers if the government was focused on improving the productivity of the existing workforce" (Savage 2012).

When approaching skills training and development, policy needs to be preemptive and not reactionary. As noted above the implications can and will be severe. According to Saunders (2012), a plateauing - and later shrinking - global population will make immigration expensive. As immigrants become scarcer, competition to lure them into post-industrial countries will increase substantially. Jim Finnigan, a human resources manager, expects the numbers of temporary foreign workers entering Canada to fill trades positions will grow significantly. As economies continue to heat up, reliance on migrant labour will increase causing competition for attracting this labour to escalate. 
This, he argues, will make this issue more important over time (Savage 2012). In light of this imminent trajectory, it would be prudent that Canadian governments begin to draw up and implement robust skills training policies and programs to hedge against possible disruptions to (im)migrant flows and prevent domestic resentment towards immigration from becoming an issue. Doing so would insulate Canada against global shortages of migrants and increase the appeal of immigration to Canadians as a complimentary tool to meet labour shortages, rather than a burdensome "deal breaker."

\section{iii. The Rise of Canadian Resentment Towards Immigration}

Continued expansion of the LSPP into new industries, whereby Canadian workers are negatively impacted by the use of temporary foreign workers to meet labour shortages, will increase levels of domestic resentment towards immigration. Although employers - through the expansion of the TFWP's LSPP into new industrial sectors have been able to fill many of the labour shortages they have experienced, the high unemployment rates in the country created by the 2008 economic crisis remain stubbornly high. This is ironic, given employers' constant and sustained calls for the government to increase levels of (im)migrant inflows. In light of high unemployment rates and increased inflows of temporary foreign workers, it will come as no surprise if Canadians, who are unemployed and are thus not being included in the country's socioeconomic development, begin to resent immigration.

The A-LMO, which allows employers to pay temporary foreign workers $15 \%$ less than Canadian workers, will interrupt inter-provincial migration (Gross 2010; AFL 2012b). By allowing employers to pay temporary foreign workers less then their 
Canadian counterparts, the government's A-LMO initiative interrupts supply and demand mechanisms. These mechanisms, which should raise wages for jobs in industries experiencing shortages, therefore do not spur unemployed workers in provinces experiencing high levels of unemployment (i.e. the Maritimes) to migrate to provinces experiencing labour shortages (i.e. Alberta and Saskatchewan).

Economically, this approach provides short-term advantages, but also imparts disadvantages in the long-term. According to Yalnizyan (2012), in the short-term, cheaper labour will benefit employers; however, in the long-term, purchasing power and growth will slow. Canadians currently affected by the TFWP's LSPP expansion into new-untouched sectors of the economy have become more wary of immigration. While $70.3 \%$ of Canadians (51.8\% agree and $18.5 \%$ somewhat agree) believe "immigration is one of the key tools Canada can use to strengthen the economy" (Nanos 2010, 10), such positive sentiment can quickly evaporate if an increasing proportion of the population feel their quality of life is threatened by (im)migration. Increasing the scope of the TFWP - through the A-LMO initiative - could act as a catalyst to reverse positive public opinion towards (im)migration.

If the government expands the scope of the A-LMO into LSPP, (which is a stated goal of HRSDC (2012a)), an increased number of Canadians would be pushed out of the middle segment of the labour market and into the secondary segment. This would exacerbate domestic antagonism towards (im)migrants and immigration in general as resident workers' wages, working conditions, benefits, and ability to access jobs are eroded (Gross 2011). Ultimately, as is the case in Europe, Canadians that feel their socioeconomic livelihoods are in jeopardy, will vote with their feet against pro immigration 
political platforms.

\section{$\checkmark$ Recommendation}

Before making any kind of recommendation about the afore-mention problem, it is necessary to assess what role (im)migration plays in Canada. Primarily, the IRPA requires that immigration impart a positive effect on Canada by increasing Canadians' standard of living (Picot \& Sweetman 2012, 9). Given Canada's increasing dependence on immigration to fuel both economic and demographic growth, it is imperative that Canadians feel positively about the effects immigration will have on them. A 2010 study on Canadians' support for immigration, found that $72.4 \%$ of the population overwhelmingly (56.3\% agree and $16.1 \%$ somewhat agree "that immigration is a key positive feature of Canada as a country") supports immigration and sees it as a positive component of the country's socio-economic development regime (Nanos 2010, 9). Yet, the study also found that a strong majority of Canadians believe (38.9\%) immigration rates should not increase more than the current 250,000-inflow rate (Nanos 2010, 9). However, for this positive attitude towards immigration to continue or even increase as the economy recovers from the 2008 economic crisis, Canadians must feel secure about their socio-economic welfare.

Continued enactment of initiatives like the RUOP, E-LMO, and A-LMO that accelerate and expand the scope of the TFWP (especially the LSPP), which have negatively impacted Canadian workers situated in the middle segments of the labour market (Preibisch 2011; Valiani 2007; Bauder 2006; AFL 2012a; Yalnizyan 2012), has already eroded some of the positive attitudes towards immigration (Gross 2011). To 
prevent further erosion and even strengthen Canadian sentiment towards immigration, the government must eliminate policies and initiatives like the RUOP, E-LMO, and A-LMO, which place Canadian workers at a disadvantage vis-à-vis temporary foreign workers. Eliminating these initiatives would slow down the speed, ease, and most importantly increase the cost for employers who want to important temporary foreign workers. As Gross points out, "one way of alleviating this adverse effect is to make temporary foreign workers as costly to access as workers from another [Canadian] region" (109).

Worth noting is Nanos' (2010) study which found that Canadians felt a remarkable degree of sympathy for the plight of temporary foreign workers in terms of their access to social services (employment insurance and workers' compensation); $55.4 \%$ of Canadians agree and $15.7 \%$ somewhat agree that temporary foreign workers "should enjoy the same rights as other workers" (11). Insuring policies and programs work in concert to strengthen both Canadian workers and temporary foreign workers' rights and livelihoods are imperative to preserving and strengthening positive Canadian sentiment towards immigration.

\section{iv. Socio-Economic Polarization}

The Decline in living standards of Canadians who are pushed into the secondary labour segment will only increase if the LSPP continues to expand. As a result, many Canadian workers' rights and work standards will decline and converge with the developing world. The increased use of temporary foreign workers to fill labour 
shortages in previously untouched sectors of the economy, in the short-term, has already caused various labour disputes ${ }^{21}$ with organized labour. As mentioned previously, these disputes have seen resident workers displaced from their jobs and replaced by temporary foreign workers that accepted lower wages, working conditions and benefits. In the longterm, especially with the enactment of the A-LMO initiative, these labour disputes are set to increase. Increased use of temporary foreign workers to settle labour disputes would further displace large swaths of resident workers in favour of hiring cheaper temporary foreign workers. As a result, Canadian workers situated in the secondary labour market will see their standard of living stagnate and/or decline.

From a LSPP temporary foreign worker's perspective, increased inflows of temporary foreign workers, who are also forced into precarious working conditions in which they receive less pay and benefits than their Canadian peers, will only further increase the size of the secondary labour market. Wages will polarize further and it will become more difficult for people (temporary foreign workers or Canadian workers) in the secondary labour market to catch-up to workers in the primary labour market. Ultimately, this has the potential of creating a much more unequal society, whereby the "haves" live in stark contrast to the "have nots." As Yalnizyan (2012) puts it, "together we [Canadians and immigrants] created an economy which today is the tenth largest in the world. While

${ }^{21}$ Disputes have occurred across various provinces and in many cases temporary foreign workers have been brought into discipline or displace Canadian workers: Park Place Seniors Living Ltd. (B.C.) (Valiani 2007); TransLink Vancouver SkyTrain vs. temporary foreign workers case (National Union 2007); Sinopec Ltd. (China state-owned oil company) case (Gray 2011). 
the economy will continue to grow, the distribution of the gains from that growth threatens to become rapidly even more lopsided."

\section{$\checkmark$ Recommendation}

To prevent further socio-economic polarization the government should reform HRSDC's LMO mechanism. To do so, it must commission a study to investigate the outcomes and effects of the continued acceleration and expansion of the LSPP into newuntouched industrial sectors; the aim of the study should be to develop a framework to adjust HRSDC's LMO mechanism to reverse these declining and polarizing trends. Given that since the creation of the TFWP's LSPP in 2002, the federal government has mostly only consulted with the private sector about how to increase the scope of the TFWP, the study must also include consultation with labour unions and NGOs. This should ensure workers' interests are included in the changes made to HRSDC's LMO process and the development of new protective mechanisms.

Such a study must assess the total effect the introduction of temporary foreign workers to a specific industry will have on Canadian resident workers and temporary foreign workers working in that specific industry. Effects on wages, working conditions, and benefits must be evaluated rigorously. Should there be any potential of decline in any of them, a mechanism - whether it be within the LMO process or an additional new process specifically designed to protect resident workers' wages, working conditions and benefits- managed by HRSDC should be mandated to prevent the issuance of LMOs for employers attempting to use the TFWP to fill labour shortages or intervene in labour disputes. An in-depth study, such as the one proposed, should go beyond the rigors of the 
current LMO criteria and look at every industry individually on a case-by-case basis.

Crucially, for reform of the LMO process to be effective, a rigorous evaluation mechanism must be built in to distinguish which industry shortages are indeed "temporary" and "permanent." If positions in certain industries require a temporary foreign worker to stay in Canada for more than a year, then the new mechanism's assessment should deem the employment shortage "permanent." Likewise, should any position require the temporary foreign workers to stay less than a year, the labour shortage should be deemed "temporary." Having these nuanced mechanisms streamlined into the LMO process would help distinguish which industries truly require "temporary " labour to be brought in. Positions that the mechanism deems permanent could qualify (im)migrants to receive full status, as they would be filling "permanent" labour shortages. Ultimately, legitimate temporary labour shortages could continue to be met through the TFWP, while legitimate permanent labour shortages could and should be met through the PNP. In this case of a streamlined permanent inflow stream, the PNP - or perhaps a new program - could be accelerated to mimic the A-LMO's processing speeds (10 business days), which would greatly speed up the labour shortage alleviation process. This would ensure permanent acute labour shortages are met in shorter time frames than the traditional FSWP normally delivers. As Naveen Mehta, of United Food and Commercial Workers Canada (UFCW), points out, "it does not improve the country's long-term economic prospects to train thousands of foreign workers and then throw them out of the country after three or four years" (Whittington 2012).

On the other hand, migrants entering the country to fill legitimate temporary labour shortages through the TFWP must be provided with adequate protection, wages, 
benefits and working conditions. As Bauder (2008) points out, "the idea that the vulnerability of many migrants and their sometimes appalling employment situations are the inevitable outcome of self-regulating labor markets and side-effects of globalization must be rejected" (327). A first step in moving towards this goal (to provide them with adequate protection, wages, benefits and working conditions) would be to eliminate the A-LMO initiative and streamline a national enforcement task force/regime to protect temporary foreign workers. The former would give Canadian workers a longer window of opportunity to apply for the jobs in industries experiencing labour shortages and reduce a wage structure dichotomy. These are crucial if the TFWP is to continue to truly help the Canadian economy leverage legitimate temporary shortages with migrant labour. In addition, a streamlined national enforcement task force/regime, which is properly staffed and funded, would reduce employer abuse of temporary foreign workers' rights, wages, and benefits. By providing an enforcement regime with teeth, the government would reduce the incentive for employers - who prefer to bring in temporary foreign workers because they more subservient due to the work permits restrictive conditions - to suppress wages, working conditions and benefits. Thus, there would be less pressure/incentive for employers to squeeze out Canadian workers situated in the middle or secondary segments of the labour market in favour of temporary foreign workers.

\section{v. The Rise of an Undocumented Underclass}

Accompanying the expansion of the TFWP's LSPP has been a rise of an undocumented underclass. The restrictive work permit, which only allows temporary foreign workers to stay in Canada for a maximum of four years, creates incentives for 
temporary foreign workers to "go underground." With reference to the LSPP's restrictive work permit, Alboim and Maytree (2009) argue this "will drive many migrants to remain in Canada underground and/or undocumented" (49). Going underground means temporary foreign workers remain after their work permits expire, leaving them fewer labour market options, not to mention exclusion from the few social services they had access to as "legal" temporary foreign workers. Exacerbating this transition into the informal economy is the lack of access to permanent status and settlement and language services. An RCMP report in 2007 estimated the number of undocumented workers in Canada to be between 200,000 and 500,000 (cited in: Contenta and Monsebraaten 2009a). However, these estimates cannot be confirmed because the government does not count/record temporary foreign workers who leave the country once their work permits expire.

The recent economic crisis and our current period of low growth have only intensified the challenges faced by temporary foreign workers in Canada. As a result, large layoffs have pushed many already vulnerable workers into an underground economy, where their undocumented status only further exacerbates their inabilities to access any basic social services or workers' rights (Contenta and Monsebraaten 2009a). Compounding the precarious nature of this labour market is the enactment of the ALMO, which will only increase the speed with which (10 business days) and the number of temporary foreign workers brought into the country. Expanding the A-LMO initiative to include LSPP, which the government has been explicit about doing (HRSDC 2012a), would certainly increase the size of this undocumented underclass to levels never seen before. Such a scenario would resemble the situation in the US in which 12 million undocumented migrant workers (Goldin 2011) live precariously vis-à-vis the resident 
population. The effects of not properly addressing the precariousness built into Canada's two-tiered immigration regime will be severe. Departing from nation building has the potential to seriously damage Canadian civil society.

\section{- Recommendation}

To resolve this problem the government must change the LSPP's restrictive work permit rules. By simply removing the four-year work permit limit and allowing LSPP temporary foreign workers to access the CEC or PNP, the government would inoculate the growing undocumented underclass problem. There is good reason to do this. Although LSPP temporary foreign workers are considered to have "lower levels" of human capital, they still accumulate considerable "Canadian experience" while working in Canada. This experience coupled with the language skills they develop in their day-today interactions with Canadians at the work place and in social settings, not to mention the social and professional networks they develop in their 1-4 year stay, makes them ideal candidates to become citizens. This is why Dave Hancock, Alberta Minister of Human Services, believes the federal government's new A-LMO initiative, which increases both the speed and ease with which employers can import temporary foreign workers, is the less "desirable option" to combat labour shortages. For example, he argues that the ideal solution would be to bring these migrants in through the Alberta Immigrant Nominee Program (AINP), which allows individuals, along with their spouse or common-law partner and dependent children, to apply for a permanent resident visa through Citizenship and Immigration Canada. In Alberta, the AINP is capped at 5,000 nominees. The province has long complained that the four-year work permit issued to temporary 
foreign workers penalizes employers that have invested significant resources to provide skills training and language training. After four years, the work permits force employers to "kick out" the workers they have invested resources in; this, the companies argue, enables other nations to benefit from the human capital the Canadian companies have invested in the temporary foreign workers (AFL 2012b).

In light of these arguments from employers and provincial leaders experiencing acute labour shortages, it is apparent that the human capital ("Canadian experience") and social networks LSPP temporary foreign workers develop needs to be retained and utilized. Having these workers and their accumulated skills and experiences be discarded and/or under-utilized and underpaid in an informal economy is not in Canada's best interest. It is a slippery slope. This could lead to serious changes to the composition of Canadian society. The rise of an underclass with no stake in its own future development is dangerous. Problems arising from the growth of an underclass include, but are not limited to, an increase in insecurity, crime, exploitation, and inequality; and decreases to living standards, social welfare services, tax revenues, work conditions, wages, and benefits. Bringing LSPP temporary foreign workers into the fold by providing them with access to pathways to the citizenship, through the CEC and PNP, is crucial to ameliorating and ultimately eliminating an undocumented underclass.

For the temporary foreign workers that are brought in to fill legitimate temporary labour shortages, the government must operationalize a tracking system to record the entry and exit of temporary foreign workers into the country. The aim of this system would be to monitor any increase or decrease of an undocumented underclass. Given that governments and policy makers need to have data and statistics to make decisions, 
implementing such a monitoring system would appear to be a good starting point. Without accurate figures on the size of the undocumented population, it is very difficult to detect some of the negative effects an expanded LSPP might incur on Canadian society. I recommend the government organize, fund and implement such a mechanism in the issuance of temporary foreign worker visas and tally them upon the temporary foreign workers' exit of Canada.

\section{vi. The "Canada Brand" will be Damaged or Devalued}

The government's realignment of principles (from long-term nation building to short-term economic and labour market priorities) to fit with employers to drive immigration policy is at the root of many of the problems surrounding the TFWP. As Picot and Sweetman (2012) point out, "while firms can lay workers off at the end of a boom or abandon their obligations as they go into bankruptcy, the nation cannot "lay off" new citizens. The planning horizons and risk profiles of business and government differ dramatically" (9). Ultimately, businesses are in the business of making money and governments are in the business of nation building and protecting their population. This divergence of interests has provided the impetus for the application of dichotomous labour relations and membership rights on temporary foreign workers vis-à-vis their immigrant counterparts.

Continuing to expand the scope of the TFWP through the LSPP will send the wrong message: Canada is not serious about immigration. This is problematic, given the importance immigration plays in driving Canada's socio-economic and demographic growth. As more and more temporary foreign workers make up a larger proportion of the 
migrant population, Canada will be labeled as an opportunistic country that is only looking for migrant labour - and not potential citizens. The exponential surge in stories since the creation and expansion of the LSPP in 2002 - of maltreated temporary foreign workers, who have been mislead by recruiters, abused by employers, and not protected by the Canadian government do not help maintain or sustain the Canadian brand as a "destination of choice." The strengths of the Canadian brand lie in its soft power: the world sees Canada as a just, democratic and equitable society that has managed to include "everyone" in it socio-economic development model. This image or brand is severely damaged when stories of an exploitative TFWP run contrary to these images of what Canada is perceived to be. Canada as a brand in the immigration world could see it's coveted "destination of choice" status be devalued or down graded. Although the "Canadian brand" encompasses many factors outside the TFWP realm, mismanagement of the LSPP could be pivotal to whether or not the Canadian brand is devalued (or not).

The implications for Canadian nation building are severe. In the long-term, as competition for migrants increases and new countries join this competition, Canada could lose potential migrants to other countries. According to Saunders (2012), "it will become much more expensive in the future, when shrinking world populations make immigrants scarce, and Canada's crisis of under population becomes expensive." Complicating matters further, reverse migration from post-industrial countries to emerging countries experiencing robust economic growth like China, India and Mexico are an emergent trend (Mackinnon 2012; Nolen 2012). For example, the Pew Hispanic Center reports rather steep declines in the number of Mexicans entering the United States, as well as the rising numbers returning to Mexico (Passel, Cohn \& Gonzalez-Barrera 2012). Currency 
fluctuations, which have seen many developing countries' currency appreciate considerably vis-à-vis the US dollar and Euro, also discourage migrants from migrating to post-industrial countries. According to Marcelo Giugale of the World Bank, "when you send dollars back to a family in Angola, they don't feel as rich as before" (The Economist 2012). These very real pressures could severely damage the Canadian nationbuilding project. Emergent countries like the ones mentioned above are eager to repatriate their original migrant populations - in many cases providing incentives to facilitate this process.

Saunders (2012) argues that the combined effects of population aging and lowbirth rates will cause Canada's old-age dependency ratio to soar. That is, the proportion of Canadians over 65 years of age, who become dependent on government social services (pensions and healthcare spending) will more than double from the current $20 \%$ to $45 \%$

of the population in 2080. This, Saunders (2012) maintains, will cause GDP growth to decline from the $2.6 \%$ annual average to a $1.8 \%$ annual average. This highlights the salience immigration and by extension nation building play in Canada's developmental trajectory. If Canada's reputation as a "destination of choice" is devalued or downgraded, its ability to grow the economy and its population could be in jeopardy. As outlined above, a decline in immigrant applicants would surely follow, not to mention the potential for reverse migration of (im)migrants already present in Canada to occur.

\section{- Recommendation}

Preserving the Canadian brand as "destination of choice" is paramount if Canada is to continue to sustain its high standard of living. While close consultation by 
government with employers should remain constant, policy towards immigration must decouple from business interests and focus on long-term nation building strategies. The government must balance its ties with the private sector with unions and other societal actors who have an interest in preserving social harmony and Canadians' quality of life.

While there is scope for the use of a TFWP that A) truly fills temporary labour shortages and B) has robust regulatory and enforcement mechanisms to protect migrants from employer abuse, this temporary migration aspect should not be the main thrust of (im)migration and labour market policy. As many critics point out (Preibisch 2011; Dobrowolsky 2011; Sharma 2006) the expansion of the TFWP through the LSPP has brought in temporary foreign workers to fill "permanently temporary" positions. Reorganizing HRSDC's LMO process - as recommended above - to distinguish which labour shortages are legitimately temporary and permanent, would be a good starting point to prevent Canada's image as a traditional country of immigration from being eroded.

To ameliorate some of the damage done by the LSPP, the government - as mentioned above - should change the LSPP's maximum 4-year cumulative duration limit and enable unskilled migrants to apply for permanent residence through the CEC or PNP. This would at least give unskilled temporary foreign workers the choice to leave or remain in the country, not to mention provide some sort of incentive for would be migrants to come to Canada. Embedding such an incentive in the TFWP's LSPP would be a prudent long-term approach that would pay dividends further down the road when competition for migrants escalates. In the end, migrants choosing a destination country will be more likely to choose a country in which they know someone or have some sort 
of family network (Yang 2010) as well as one that has a clean record when it comes to its treatment of migrants. As Cameron \& Goldin (2012) point out, "prosperity in the $21 \mathrm{st}$ century will come to those countries that are able to recognize and harness the benefits of greater global mobility." It is therefore critical that Canada get its immigration system right.

In many ways this competition between post-industrial countries for socioeconomic and demographic growth through immigration has already begun. For example, Australia has recently begun the "Big Australia" movement, which is aimed at doubling the country's population through accelerated immigrations mechanisms and programs (Saunders 2012). Saunders (2012) argues, “we need a 'Big Canada' movement and given our economic needs, our labour shortages and the continuing pains of under population - this is the time to launch it." For such a necessary and ambitious strategy to succeed, the Canadian brand must be seen to provide the best opportunities to migrants worldwide - or at least competitively positioned vis-à-vis its competitors. To compliment a "Big Canada" immigration policy and improve the image of Canada's - hopefully downsized - TFWP, the government could help improve governance of global migration. Supporting a rules-based system that fosters closer cooperation and protection of migrants' human-rights between origin and receiving countries, Cameron \& Goldin (2012) argue, would not only improve the country's current ad hoc approaches, it would also send a clear "message to the world that Canada embraces the contribution migrants make to its own society and economy. This kind of leadership would also cement Canada's position as a preferred destination for the world's aspiring workers, thinkers and innovators." 


\section{Conclusion}

Goldin et al. (2011) believe that even if there is a substantial reduction in inequality in sending countries, future pressures to migrate to developed countries will not abate, due in part to the positive effect that increased incomes in emerging countries have on people's propensity to emigrate. That is, as poor countries become richer, they produce a rising supply of migrants that have the economic capacity to migrate (221). In Canada's case, this increased inflow will most likely continue. However, the proportion of temporary foreign workers - driven by employer demands - will probably continue to eclipse permanent immigration. As this paper has demonstrated, the effects of global restructuring, engendered through neoliberal ideologies and practice, have enabled organized capital to inform and articulate (im)migration policy, and by extension, labour market policy. Critically, the state's baptism of "market led" citizenship principles which emphasize the dilution of wages, benefits and rights - has pushed not only temporary foreign workers, but also resident workers situated in unskilled labour sectors to the margins of socio-economic development. This is not to say these resident workers are as vulnerable as unskilled temporary foreign workers. The point here is that resident workers (situated in middle segments of the labour market) and temporary foreign workers both "lose" in this new paradigm.

In terms of the theoretical perspectives discussed in section one, it is apparent that labour segmentation theory provides a more nuanced lens from which to analyze the growth of temporary migrant regimes in post-industrial countries. The idea that 
developmental disparities are so great that some people moving across borders should be restricted vis-à-vis local residents should be rejected. Arguments that emphasize the "developmental" gains accrued to the Global South though equilibrium theory, even under such restrictive conditions, are problematic. Real development should increase the socio-economic welfare of everyone, on both sides of the border; and not use such socioeconomic disparities experienced by one group to discipline the other into subservience. The argument by Ruhs \& Martin (2008), and other similar justifications from development economists ${ }^{22}$ (Pritchett 2006; Lenard \& Straehle 2010) that the expansion of temporary migrant regimes is a "win-win-win ${ }^{23}$," simply does not add up. My findings demonstrate that the use and expansion of temporary migrant regimes in post-industrial countries negatively affect Canadian workers and temporary foreign workers. Instead of this being a "win-win-win," it is a "win-lose-lose." The only winners, as my findings demonstrate, are employers. For this reason, labour segmentation theory takes better account of the negative "lose-lose" processes occurring in post-industrial countries, including Canada.

Canada proudly touts its supremacy as the only country that naturalizes $85 \%$ of the immigrants it receives - the U.S. naturalizes $40 \%$ and in Europe the figures are even

${ }^{22}$ Pritchett (2006) and Lenard \& Straehle (2010) argue, although migrants brought in to post-industrial countries through temporary migrant regimes are exploited, the range of benefits resulting from the global redistribution of wealth - through remittances - is justified. That is, it is necessary to sacrifice migrant rights to help redistribute wealth to the developing world.

${ }^{23}$ The argument is that migrant workers win by earning higher wages while working in receiving countries, post-industrial countries win by quickly filling "temporary" labour shortages and leveraging industrial output, and sending countries win through the increased flows of remittances and "skill/technology transfers" of returning migrants to the origin country (Ruhs and Martin 2008, 249). 
lower (Saul 2008, 46). Saul (2008) argues, "unlike cities in Europe or the United States, in which interesting mixtures are also being created, ours are entirely international experiments and are built around an initial assumption of shared citizenship" (46). However, as this paper has demonstrated the neoliberalization of immigration and organized capital's persuasive influence, coupled with the Canadian state's use of citizenship principles and laws to divide unskilled and skilled migrants into temporary and permanent (im)migrants streams, drastically challenges this "shared citizenship" concept. The fact that the TFWP has eclipsed the FSWP is evidence that Canada really does not even naturalize half of the (im)migrants entering its territory.

The truth of the matter is, unskilled migrants will not have the same opportunities offered to previous Canadian immigrants. Any possibility of integration and participation, engendered through permanent immigration regimes, will and are being diminished. Instead, the exclusionary laws inherent in the LSPP will, and are pushing migrants into an informal underworld, hidden from the mainstream's view. The 2008 economic crisis and our current period of low growth have only intensified these challenges. As a result, layoffs and the LSPP's cumulative duration regulation (four year maximum stay) have pushed many already vulnerable workers into underground economies, where their undocumented status only further exacerbates their inabilities to access any basic rights. The growth of this underworld has the potential to fundamentally change Canada's socioeconomic profile. One that would mirror the TFWP's two-tiered model of "haves" and "have-nots."

Alboim and Maytree (2009) rightly point out, "as more people go underground, Canada will face problems like those European countries experienced with their guest 
workers in the 1960's and 70's and by the United States with its illegal immigrants" (44). To avoid this catastrophic socio-economic calamity, Canada and society at large must recognize the exploitative and unethical nature of the two-tiered (im)migration system, and immediately eliminate the LSPP or adapt it to provide access to permanency. Reverting back to Canada's traditional single-tiered permanent status immigration system, which essentially espoused the principle of $j u s$ domicile by filling the gaps left by jus soli and jus sanguinis, would cost more in the short-term, but would cost less and render positive dividends in the long-term.

Although the whole idea behind signing free trade agreements - which is one of the major tenets within theories of globalization - was to bring the "first world" to the "third world," we have actually seen the importation of "third world" labour standards to the "first world" (Roel van den Cate 2009). Even within our current "competition paradigm," which is underpinned by globalization, the state coupled with organized capital manipulates immigration policies to reposition itself in the global industrial pecking order. This departure from traditional immigration is problematic. Historically, Canada has thrived by espousing a "single-tiered" immigration system. In fact, it is clear that Canada's prosperity has hinged on immigrants' access to equal rights and citizenship. Not adhering to the country's fundamental strengths embedded in legislation like the Charter of Rights and Freedoms, which espouses principles of democracy and equality, will devalue Canada's reputation as a "destination of choice" and ultimately its future prosperity. 


\section{Bibliography}

Abella, M. (2006). Policies And Best Practices For Management Of Temporary

Migration. United Nations: Population Division Department of Economic and Social

Affairs. Retrieved April 16, 2012, from

http://www.un.org/esa/population/migration/turin/Symposium_Turin files/P03 SYMP

Abella.pdf

Alboim, N., \& Maytree. (2009). Adjusting the Balance: Fixing Canada's Economic Immigration Policies. Maytree: leaders for change. Retrieved April 2, 2012, from http://www.maytree.com/wp-content/uploads/2009/07/adjustingthebalance-final.pdf

Alberta Federation Of Labour (AFL 2012a). New Rules Allowing Employers To Pay Temporary Foreign Workers Less Than Canadians Will Drive Wages Down And "Pit Workers Against Workers". Retrieved May 17, 2012, from http://www.afl.org/index.php/PressRelease/new-rules-allowing-employers-to-pay-temporary-foreign-workers-less-thancanadians-will-drive-wages-down-and-pit-workers-against-workers.html

Alberta Federation of Labour. (2012b). Editorial: Temporary Foreign Worker Program Is A Necessary Evil | AFL in the News | Alberta Federation of Labour Retrieved May 7, 2012, from http://www.afl.org/index.php/AFL-in-the-News/editorial-temporary-foreignworker-program-is-a-necessary-evil.html

Austin, C., Bauder, H. (2010). Jus Domicile: A Pathway To Citizenship For Temporary Foreign Workers?. CERIS - The Ontario Metropolis Centre. 2-14. http://ceris.metropolis.net/wpcontent/uploads/pdf/research_publication/working_papers/wp81.pdf

Bagchi, A. K. (2008). Immigrants, Morality And Neoliberalism. Development and Change, 39(2), 197-218. doi:10.1111/j.1467-7660.2007.00476.x

Bauder, H. (2008). Citizenship As Capital: The Distinction Of Migrant Labor. Alternatives: Global, Local, Political, 33(3), 315-333. doi:10.1177/030437540803300303

Bauder, H. (2006). Labor Movement: How Migration Regulates Labor Markets. New York City. USA: Oxford UP, 2006. Print.

Beine, M., Coulombe, S., \& Vermeulen, W. (2012). Dutch Disease and the Mitigation Effect of Migration: Evidence from Canadian Provinces.University of Luxembourg, IRES, CREAM and CES-Ifo. Retrieved April 15, 2012, from http://www.michelbeine.be/pdf/Beine, $\% 2$

Canada. Parliament of Canada (2009). Government of Canada Response to the Report of the Standing Committee on Citizenship and Immigration: Temporary Foreign Workers and Non-Status Workers. 
http://www.parl.gc.ca/HousePublications/Publication .aspx? Language $=\&$ Mode $=1 \&$ Parl $=4$ $0 \&$ Ses $=2 \&$ DocId $=4017803 \&$ File $=0$

Canada. House of Commons Canada (2009). Standing Committee on Citizenship and Immigration.Temporary Foreign Workers and Non-status Workers. http://dsppsd.pwgsc.gc.ca/collection_2009/parl/XC64-402-1-1-01E.pdf

Canada. (CIC 2011), Citizenship and Immigration Canada. Annual Report to Parliament on Immigration. http://www.cic.gc.ca. Retrieved March 16, 2012, from http://www.cic.gc.ca/english/pdf/pub/annual-report-2011.pdf

Canada. (CIC 2010a), Citizenship and Immigration Canada. Facts and Figures $2010-$ Immigration Overview: Permanent and Temporary Residents. http://www.cic.gc.ca. Retrieved March 16, 2012, from http://www.cic.gc.ca/english/resources/statistics/facts2010/temporary/06.asp

Canada. (CIC 2010b). Citizenship and Immigration Canada. Labour Market Opinion Basics. Retrieved May 15, 2012, from http://www.cic.gc.ca/english/work/employers/lmobasics.asp\#basics

Canada. (CIC 2010c). Citizenship and Immigration Canada. Backgrounders - Improvements to the Temporary Foreign Worker Program. (n.d.). Welcome Page | Page d'accueil. Retrieved May 26, 2012, from http://www.cic.gc.ca/english/department/media/backgrounders/2010/2010-08-18.asp

Canada (CIC 2008)Canadian Experience Class. Welcome Page | Page d'accueil. Retrieved August 20, 2012, from http://www.cic.gc.ca/english/immigrate/cec/index.asp

Canada. (CIC 2007). Citizenship And Immigration Canada. Backgrounder - Improvements To The Foreign Worker Program. (n.d.).Welcome Page | Page d'accueil. Retrieved May 26, 2012, from http://www.cic.gc.ca/english/department/media/backgrounders/2007/200702-23.asp

Canada. (HRSDC 2012a).Human Resources And Skills Development Canada. TFWP A-LMO Fact Sheet. (2012, May 17). Human Resources and Skills Development Canada. Retrieved May 26, 2012, from http://www.hrsdc.gc.ca/eng/workplaceskills/foreign_workers/almo/factsheet.shtml

Canada. (HRSDC 2012b). HRSDC Assessment Criteria For Job Offers In Occupations That Require A High School Diploma Or Job-Specific Training. (n.d.). Human Resources and Skills Development Canada. Retrieved August 20, 2012, from http://www.hrsdc.gc.ca/eng/workplaceskills/foreign_workers/lsasse.shtml

Canadian Charter of Rights and Freedoms. (n.d.). Justice Laws Website | Site Web de la lagislation (Justice). Retrieved March 28, 2012, from http:/lawslois.justice.gc.ca/eng/charter/ 
Calgary Herald. (2009, November 15). No Such Thing As A Bad Job, Flaherty Tells Picky Unemployed Workers. Retrieved May 21, 2012, from

http://www.calgaryherald.com/business/No\%20such\%20thing $\% 20 \mathrm{as} \% 20 \mathrm{a} \% 20 \mathrm{bad} \% 20 \mathrm{jo}$

b,\%20Flaherty\%20tells\%20picky\%20unemployed\%20workers/6624254/story.html

Cameron, G., \& Goldin, I. (2009, November 14). Harnessing Immigrant Mobility Means Prosperity For All Canadians. The Globe and Mail . Retrieved May 22, 2012, from http://www.theglobeandmail.com/news/national/time-to-lead/harnessing-immigrantmobility-means-prosperity-for-all-canadians/article2432425/

Carens, J. H. 2008. 'Live-In Domestics, Seasonal Workers, And Others Hard To Locate On The Map Of Democracy.' The Journal of Political Philosophy: 1-27.

Castles, S. \& Miller, M. J. (2009). The State And International Migration: The Quest For Control. The Age of Migration: International Population Movements in the Modern World. Basingstoke: Palgrave Macmillan. Print.

Castles, S. (2006). 'Guestworkers In Europe: A Resurrecton?' International Migration Review 40(4): 741-766.

Castles, S. (2005). Nation And Empire: Hierarchies Of Citizenship In The New Global Order. International Politics, 42(2), 203-224.

Castles, S. (2007). Comparing the Experience of Five Major Emigration Countries. International Migration Institute Working Paper. Oxford: International Migration Institute.

Castles, S. (2000) Citizenship And The Other In The Age Of Migration. Ethnicity and Globalization: from Migrant Worker to Transnational Citizen. London: Sage Publications, 2000. Print.

Chaloff, J., \& Lemaître, G. (2009). Managing Highly Skilled Migration: A Comparative Analysis of Migration Policies and Challenges in OECD Countries. OECD Social, Employment and Migration Working Papers, 79. Retrieved April 16, 2012, from http://www.oecd-ilibrary.org/social-issues-migration-health/managing-highly-skilledlabour-migration_225505346577

Chidley, D. (2012, February 8). Ontario Crash Kills Farm Workers And Raises Questions About Passenger Van Safety. The Toronto Star. Retrieved March 16, 2012, from http://www.thestar.com/article/1127720--ontario-crash-kills-farm-workers-and-raisesquestions-about-passenger-van-safety

Cohen, R. (1987). The New Helots: Migrants In The International Division Of Labour (Aldershot, UK: Avebury, 1987), p. 135. 
Contenta, S., \& Monsebraaten, L. (2009, November 1). How We're Creating an Illegal Workforce . The Toronto Star. Retrieved May 10, 2012, from http://www.thestar.com/news/investigations/article/719355--how-we-re-creating-anillegal-workforce

Curry, B. (2012, May 16). Help Wanted: Ottawa Withholding EI Reform Details. The Globe and Mail . Retrieved May 22, 2012, from http://www.theglobeandmail.com/news/politics/help-wanted-ottawa-withholding-eireformdetails/article2435193/?utm_medium=Feeds\%3A\%20RSS\%2FAtom\&utm_source=Politi cs\&utm content $=2435193$

Depatie-Pelletier, E. (2011). Federal Reforms And The Silence Of Abused Migrant Workers In Canada. The Canadian Foundation for the Americas (FOCAL). Retrieved May 16, 2012, from http://www.focal.ca/publications/focalpoint/465-june-2011-eugenie-depatiepelletier-en

Dobrowolsky, A. (2011). The Intended And Unintended Effects Of A New Immigration Strategy: Insights From Nova Scotia's Provincial Nominee Program. Studies in Political Economy, (87), 109.

Friesen, J. (2012, May 14). Canada Ready To Open Its Doors To More Immigrants, Kenney Says. The Globe and Mail. Retrieved May 15, 2012, from http://www.theglobeandmail.com/news/national/time-to-lead/canada-ready-to-open-itsdoors-to-more-immigrants-kenney-says/article2433975/page2/

Fudge, J. (2011). The Precarious Migrant Status and Precarious Employment: The Paradox of International Rights for Migrant Workers. Metropolis British Columbia: Centre of Excellence for Research on Immigration and Diversity, Retrieved March 19, 2012, from http://mbc.metropolis.net/assets/uploads/files/wp/2011/PBN11-15.pdf

Galloway, D. (2001). Citizenship Rights and Non-Citizens: A Canadian Perspective. Citizenship in a Global World: Comparing Citizenship Rights for Aliens. Ed. Atsushi Kondo. Houndmills, Basingstoke, Hampshire: Palgrave, 2001. 176-95. Print.

Gilbert, R. (2012, May 2). Unions Decry Temp Worker Rule Changes. Journal Of Commerce: Western Canada's Construction Newspaper. Retrieved May 6, 2012, from http://www.journalofcommerce.com/article/id49954/--unions-decry-temp-worker-rulechanges

Goldin, I., Cameron, G., \& Balarajan, M. (2011). Exceptional People: How Migration Shaped Our World And Will Define Our Future. Princeton: Princeton University Press.

Goldring, L., Berinstein, C., \& Bernhard, J. K. (2009). Institutionalizing Precarious Migratory Status In Canada. Citizenship Studies, 13(3), 239-265. 
Gomez, T. (2011). Low-skill Temporary Work and Non-access to Permanent Residence. "FOCAL: Canadian Foundation for the Americas, 1-8.

Gray, J. (2011, September 27). Sinopec, The Oil Sands And Justice Delayed. The Globe and Mail. Retrieved March 15, 2012, from http://www.theglobeandmail.com/report-onbusiness/industry-news/the-law-page/sinopec-the-oil-sands-and-justicedelayed/article2182473/

Green, Alan G. (2003). “What is the Role of Immigration in Canada's Future?' Ed. Charles M. Beach, Alan G. Green, and Jeffrey G. Reitz, eds. Canadian Immigration Policy for the $21^{\text {st }}$ Century. Montreal: McGill-Queens University Press.

Gross, D. M. (2011). Who Feels Economically Threatened by Temporary Foreign Workers? Evidence from the Construction Industry. The Economic Society of Australia, 30.4, 53045.

Gross, D. M. (2010). Temporary Foreign Workers in Canada: Does a Policy with Short-term Purpose Have a Long-term Impact on Unemployment? The Metropolis Project: Canadian Issues (Temporary Foreign Workers), 107-11. Retrieved April 15, 2012, from http://canada.metropolis.net/pdfs/cdn_issues_CITC_mar10.pdf

Haan, M. (2008). The Place Of Place: Location And Immigrant Economic Well-Being In Canada. Population Research and Policy Review, 27(6), 751-771. doi:10.1007/s11113008-9092-7

Harder, Lois (2001) “The Modern State' in Janine Brodie.” Ed. Critical Concepts: An Introduction to Politics. Scarborough: Prentice-Hall.

Harris, N. (2006). "Chapter 9 Migration of Labour: Constructing Transnational Arrangements." Ed. Rajarshi Ghosh and Asis Humar Pain. Migration of Labor: Global Perspective. Hyderabad: ICFAI UP, Print.

Hennebry, J. (2010). Who has their eye on the ball? "jurisdictional fútbol” and canada's temporary foreign worker program. IRPP Study. Retrieved April 11, 2012, from http://www.irpp.org/po/archive/jul10/hennebry.pdf

Kelley, N., \& Trebilcock, M. J. (2010). The Making Of The Mosaic: A History Of Canadian Immigration Policy (2nd ed.). Toronto: University of Toronto Press.

Keung, N. (2012, July 2). Ontario's Injured Migrant Workers Lose Out On WSIB Benefits, Critics Charge. The Toronto Star. Retrieved July 26, 2012, from http://www.thestar.com/news/gta/article/1220483--ontario-s-injured-migrant-workerslose-out-on-wsib-benefits-critics-charge

Lenard, P. T., \& Straehle, C. (2010). Temporary Labour Migration: Exploitation, Tool Of Development, Or Both?. Policy and Society, 29(4), 283-294. 
Mackinnon, M. (2012, May 13). China Lures Back Its Best. The Globe and Mail . Retrieved May 29, 2012, from http://www.theglobeandmail.com/news/national/time-to-lead/china-luresback-its-best/article2431479/

Macklin, A. (2010). Freeing Migration From The State: Michael Trebilcock On Migration Policy. University of Toronto Law Journal , 60(2), 315-348.

MacLeod, C. (2008, Aug 13, 2008). Initiatives To Bring More Workers. Leader Post, pp. D.2.

Marsden, S (2011). Assessing The Regulation Of Temporary Foreign Workers In Canada. Osgoode Hall Law Journal, 49(1), 39.

McBride, S. (2005). Paradigm Shift: Globalization And The Canadian State. Halifax, N.S.: Fernwood. Print

Nakache, D., Kinoshita, P. J. (2010). Institute for Research on Public Policy, \& ebrary, I. The Canadian Temporary Foreign Worker Program: Do Short-Term Economic Needs Prevail Over Human Rights Concerns? Retrieved March 16, 2012, from http://www.irpp.org/pubs/irppstudy/irpp_study_no5.pdf

Nanos, N. (2010). Canadians Strongly Support Immigration, But Don't Want Current Levels Increased. Institute for Research on Public Policy. Retrieved May 23, 2012, from http://www.irpp.org/po/archive/jul10/nanos.pdf

National Union. (2007). Canada: The Land of Denied Opportunity? A Review of Canada's Temporary Foreign Workers Program. National Union of Public and General Employees (NUPGE), 0. Retrieved March 16, 2012, from http://www.nupge.ca/files/publications/Land_of_Denied_Opportunity.pdf

New rivers of gold: Remittances From Unlikely Places Are Helping Poor Countries In The Downturn. (2012, April 28). The Economist. Retrieved May 15, 2012, from http://www.economist.com/node $/ 21553458$ ? fsrc $=\mathrm{scn} \% 2 \mathrm{Ffb} \% 2 \mathrm{Fwl} \% 2 \mathrm{Far} \% 2 \mathrm{Fnewriverso}$ fgold

Nolen, S. (2012, May 13). For Many Indians, The Land Of Opportunity Is The Land They're Going Back To. The Globe and Mail . Retrieved May 28, 2012, from http://www.theglobeandmail.com/news/national/time-to-lead/for-many-indians-the-landof-opportunity-is-the-land-theyre-going-back-to/article2431478/

Pacholik, B. (2012, May 2). Foreign Worker Disappointed By Sask. Experience. Leader-Post. Retrieved May 7, 2012, from http://www.leaderpost.com/news/Foreign+worker+disappointed+Sask+experience/65505 56/story.html 
Passel, J., Cohn, D., \& Gonzalez-Barrera, A. (2012). Net Migration from Mexico Falls to Zeroand Perhaps Less. Pew Hispanic Center. Retrieved May 17, 2012, from http://www.pewhispanic.org/files/2012/04/Mexican-migrants-report_final.pdf

Picot, G., \& Sweetman, A. (2012). Making It in Canada: Immigration Outcomes and Policies. Institute for Research on Public Policy, 29. Retrieved May 25, 2012, from http://www.irpp.org/pubs/IRPPstudy/IRPP_Study_no29.pdf

Piore, M. J. (1979). Birds Of Passage: Migrant Labor And Industrial Societies. New York: Cambridge University Press

Preibisch, K. (2011). Migrant Workers and Changing Work-place Regimes in Contemporary Agricultural Production in Canada. International Journal of Sociology of Agriculture and Food, 19(1), 62-82.

Pritchett, L. (2006). Let Their People Come: Breaking The Gridlock On Global Labor Mobility. Washington, D.C.: Center for Global Development.

Roel van den Cate. (2009). The Impact Of International Trade On Less Developed Countries. Business Intelligence Journal, 2(1), 113-138.

Rowles, M. (2003). Towards An Inclusive Information Society: The Experience Of Workers And Working People. British Columbia Government and Service Employees' Union. Retrieved May 21, 2012, from http://www.oecd.org/dataoecd/9/45/2499535.pdf

Ruhs, M., \& Martin, P. (2008). Numbers Vs. Rights: Tradeoffs And Guest Worker Programs. International Migration Review, 42(1), 249-265.

Russel, J. V. (2012, May 22). Foreign Workers 'Will Hurt' Alberta Employees, Labour Leader Says Read more: The Calgary Herald. Retrieved May 25, 2012, from http://www.calgaryherald.com/business/Foreign $\% 20$ workers $\% 20 \% \mathrm{E} 2 \% 80 \% 98$ will $\% 20 \mathrm{~h}$ urt $\%$ E2\%80\%99\%20Alberta $\% 20$ employees, $\% 20$ labour $\% 201$ eader $\% 20$ says $/ 6656100 /$ stor y.html

Saul, J. R. (2008). A Fair Country: Telling Truths About Canada. Toronto: Penguin Canada. Print

Saunders, D. (2012, May 17). What Would A Canada Of 100 Million Feel Like? More Comfortable, Better Served, Better Defended. The Globe and Mail. Retrieved May 24, 2012, from http://www.theglobeandmail.com/news/national/time-to-lead/what-would-acanada-of-100-million-feel-like-more-comfortable-better-served-betterdefended/article2436609/

Savage, L. (2012, May 22). U.S. Workers: Need Job, Can't Travel To Alberta. Macleans. Retrieved May 24, 2012, from http://www2.macleans.ca/2012/05/22/need-job-will-travel/ 
Schumpeter, J. A., (1994). Capitalism, Socialism, And Democracy. New York: Harper \& Broth. Print

Sharma, N. R. (2006). Home Economics: Nationalism And The Making Of 'Migrant Workers' In Canada. Toronto: University of Toronto Press.

Siemiatycki, M. (2010). Marginalizing Migrants: Canada's Rising Reliance On Temporary Foreign Workers. The Metropolis Project: Canadian Issues (Temporary Foreign Workers), 60-64. Retrieved March 14, 2012, from http://canada.metropolis.net/pdfs/cdn_issues_CITC_mar10.pdf

Simmons, A. (2010). Immigration And Canada: Global And Transnational Perspectives

Tilson, D. (2009). Temporary Foreign Workers And Nonstatus Workers . House Of Commons Canada, (40th Parliament, 2nd Session). Retrieved May 8, 2012, From Http://DspPsd.Pwgsc.Gc.Ca/Collection_2009/Parl/XC64-402-1-1-01E.Pdf

Thomas, D. (2010). Foreign Nationals Working Temporarily In Canada. Statistics Canada: Canada's National Statistical Agency. Retrieved April 9, 2012, from http://www.statcan.gc.ca/pub/11-008-x/2010002/article/11166-eng.htm

Trumper, R., Wong L. (2010). Temporary Foreign Workers in Canada: A National Perspective. The Metropolis Project: Canadian Issues (Temporary Foreign Workers), 8388. Retrieved March 14, 2012, from http://canada.metropolis.net/pdfs/cdn_issues_CITC_mar10.pdf

Tomie, L. (2010). Responsible Recruitment of Temporary Foreign Workers in Canada. The Metropolis Project: Canadian Issues (Temporary Foreign Workers) , 03188442, 104-6. Retrieved April 16, 2012, from http://canada.metropolis.net/pdfs/cdn_i

Turner, J. (2012, July 2). Company Fined \$12,000 In Illegal Worker Bust. Company Fined $\$ 12,000$ In Illegal Worker Bust. The Toronto Sun. Retrieved July 10, 2012, from http://www.torontosun.com/2012/07/02/company-fined-12000-in-illegal-worker-bust

Valiani, S. (2007). Analysis, Solidarity, Action-A Workers' Perspective On The Increasing Use Of Migrant Labour In Canada. Canadian Labour Congress. Social And Economic Policy Department. Retrieved March 14, 2012, from http://bcfed.ca/files/AnalysisSolidarity

Vanderklippe Payne, L. (2012, May 19). The Conservatives And The Junk Labour Market. The Telegram. Retrieved May 21, 2012, from http://www.thetelegram.com/Opinion/Columns/2012-05-19/article-2982886/TheConservatives-and-the-junk-labour-market/1

Walia, H. (2010). Transient Servitude: Migrant Labour In Canada And The Apartheid Of Citizenship. Race and Class, 52(1), 71-84. 
Wallerstein, I. (2000). Globalization Or The Age Of Transition?: A Long-Term View Of The Trajectory Of The World-System. International Sociology, 15(2), 249-265.

Walton, D. (2012, June 12). Immigrants With Assets Make The Perfect 'Recipe For Unscrupulous Folks'. The Globe and Mail. Retrieved June 14, 2012, from http://www.theglobeandmail.com/news/national/immigrants-with-assets-make-theperfect-recipe-for-unscrupulous-folks/article4254222/

Watt, D., Krywulak, T., \& Kitagawa, K. (2008). Renewing Immigration Towards A Convergence And Consolidation Of Canada's Immigration Policies And Systems. Conference Board of Canada. Retrieved April 10, 2012, from http://www.conferenceboard.ca/Librarie

Wayland, S. (2006). The Politics Of Transnationalism: Comparative Perspectives. Edited by Wong, L. L., \& Satzewich, V. Transnational identities and practices in Canada.

Westlake, K. (2010). Think Local, Recruit Global: The Role Of The Temporary Migrant Workers In Canadian Food Production. A Journal Of Undergraduate And Community Research. Http://convergencejournal.ca/. Web. 28 Nov. 2011. http://convergencejournal.ca/archives/89

Whittington, L. (2012, May 15). Conservatives' Wage Model Will Hurt All Workers, Unions Say. The Toronto Star. Retrieved May 16, 2012, from http://www.thestar.com/news/canada/article/1178645--wage-reform-unions-say-harper-spay-less-wage-model-will-hurt-all-workers

Yalnizyan, A. (2012, May 3). Changes To Immigration Policy Could Transform Society. The Globe and Mail. Retrieved May 3, 2012, from http://www.theglobeandmail.com/reporton-business/economy/economy-lab/the-economists/changes-to-immigration-policycould-transform-society/article2420367/

Yang, P. Q. (2010). A Theory Of Asian Immigration To The United States. Journal of Asian American Studies, 13(1), 1. 